\title{
Review on bisphenol A and the risk of polycystic ovarian syndrome: an insight from endocrine and gene expression
}

\author{
Risani Mukhopadhyay ${ }^{1}$. Navya B. Prabhu ${ }^{1} \cdot$ Shama Prasada Kabekkodu ${ }^{2} \cdot$ Padmalatha S. Rai $^{1}$
}

Received: 20 December 2021 / Accepted: 11 February 2022 / Published online: 24 February 2022

(c) The Author(s) 2022

\begin{abstract}
Bisphenol A (BPA) is one of the most widely studied endocrine disrupting chemicals because of its structural similarity to 17- $\beta$ estradiol; its ability to bind as an agonist/antagonist to estrogen receptors elicits adverse effects on the functioning of the metabolic and endocrinal system. Therefore, BPA has been thoroughly scrutinized concerning its disruption of pathways like lipid metabolism, steroidogenesis, insulin signaling, and inflammation. This has resulted in reports of its correlation with various aspects of cardiovascular diseases, obesity, diabetes, male and female reproductive disorders, and dysfunctions. Among these, the occurrence of the polycystic ovarian syndrome (PCOS) in premenopausal women is of great concern. PCOS is a highly prevalent disorder affecting women in their reproductive age and is clinically characterized by hyperandrogenism, ovulatory dysfunction, and polycystic ovarian morphology, along with metabolism-related dysfunctions like hyperinsulinemia, obesity, and insulin resistance. In this review, we analyzed certain researched effects of BPA, while focusing on its ability to alter the expression of various significant genes like GnRH, AdipoQ, ESR1, StAR, CYP11A1, CYP19A1, and many more involved in the pathways and endocrine regulation, whose disruption is commonly associated with the clinical manifestations of PCOS.
\end{abstract}

Keywords Polycystic ovarian syndrome $\cdot$ Bisphenol A · Hormones · Gene expression $\cdot$ Steroidogenesis · Gonadotropins

\section{Introduction}

As time passes and human needs evolve, there is a demand for the modernization of industries. This causes high production rates of various chemicals. Some of these chemicals may have harmful effects on the body of both humans and animals. One such class of chemicals is known as endocrinedisrupting chemicals (EDCs). They are a heterogeneous group of molecules that are of both synthetic and natural origin and possess the ability to mimic or antagonize natural

Responsible Editor: Lotfi Aleya

Padmalatha S. Rai

padmalatha.rai@manipal.edu

1 Department of Biotechnology, Manipal School of Life Sciences, Manipal Academy of Higher Education, Manipal, India

2 Department of Cell and Molecular Biology, Manipal School of Life Sciences, Manipal Academy of Higher Education, Manipal, India hormones and can interact with hormone receptors (Yilmaz et al. 2020).

Among various types of EDCs, the most abundantly available chemical is bisphenol A (BPA). It is a white, crystalline solid compound of synthetic nature, which serves as a precursor to polycarbonates, polyesters, polysulfones, polyether ketones, and a major class of epoxy resins (vinyl ester resins). Due to its properties, it has been classified as a plasticizer. Hence, it has an extensive range of applications and is commonly found in baby bottles, metal-based food, beverage can linings, ophthalmic lenses, medical and dental supplies, electronics and electric appliances, water pipes, and carbonless receipt (Yilmaz et al. 2020). Since BPA is small in structure and is lipophilic in nature, it gives it the ability to cross cellular barriers and bio-accumulate in adipose tissues of most animals and humans, thereby accommodating its participation in various reactions that take place in the body (Rutkowska and Rachoń 2014).

BPA has been identified as a xenoestrogen, because of its ability to disturb the functioning of the endocrine system by mimicking the behavior of the natural estrogen, $17-\beta$ estradiol (Iso et al. 2006). Its activity was defined towards 
classical nuclear $\mathrm{ER}_{\alpha}$ and $\mathrm{ER}_{\beta}$ receptors, their expression, interactions, and effect on steroidogenesis. Due to such disruptions, the subsequent effects observed are in the growth of ovarian follicles, enlarged prostate, increased bodyweight, alterations in testosterone excretion, and sperm quality (Melzer et al. 2011; Richter et al. 2007).

BPA is observed to show moderately acute toxicity in animals, especially mammals. It has been reported to show effects on the functioning of other hormones like androgens, insulin, prolactin, and thyroid hormone (Wetherill et al. 2007; Renaud et al. 2019). The most common pathological effects observed in laboratory studies with and peer-reviewed human studies are obesity, cardiovascular diseases, hyperinsulinemia, thyroid, hypertension, ovarian and testicular developmental issues, polycystic ovarian syndrome (PCOS), and cancer (Michałowicz 2014). BPA tends to affect various pathways like the insulin pathway, glucose pathway, lipid metabolism, protein metabolism, and ovarian steroidogenesis, thereby having the potential to cause metabolic-endocrine disorders like PCOS in premenopausal women. PCOS is an extremely prevalent metabolic endocrine disorder in premenopausal women, displaying a broad spectrum of clinical manifestations and subsequent associative morbidities (Belenkaia et al. 2019). It is a heterogeneous disorder that is characterized by a combination of symptoms and manifestations of excess androgen in the form of hyperandrogenism and/or hirsutism, ovarian dysfunction both morphological and endocrinal, and menstrual irregularities observed as the number of cycles per year or the length of each cycle.

The worldwide prevalence of PCOS is estimated to range from 4 to 12\% (Meier 2018) making it one of the most common endocrine-metabolic disorders in women during their reproductive age. Despite this, PCOS continues to be one of the poorly understood medical disorders among, patients, practitioners, pharmaceuticals, and even the research community (Escobar-Morreale 2018). Over the decades, research on PCOS has suggested that it is multifaceted in nature and there are various factors like genetic (gene interactions and effect of environment on gene expression), epigenetic (modifications and alterations), endocrine, metabolic, environmental factors, and lifestyle that influence the onset of PCOS in women (Prabhu et al. 2021).

\section{Human interaction with BPA}

Exposure in humans can be classified into two broad categories, environmental exposure and intake from food. The possible routes of exposure are ingestion, inhalation, and dermal uptake in humans. Environmental exposure is due to various factors such as BPA leaching into the atmosphere or water bodies by industrial activities, dumping of waste in landfills, and many more. Whereas the exposure due to intake of food is related to the interaction of plants and animals with BPA, the consequent bioaccumulation, and the contact of food with packaging materials (Kang et al. 2006). Unlike most EDCs, BPA has a short half-life of $6 \mathrm{~h}$ and has the ability to get eliminated as BPA-glucuronide due to enzyme activity under normal conditions. Yet, it is considered to be persistent because of its widespread application and continuous exposure of the population to it (Encarnação et al. 2019). Therefore, to set a safety level of exposure to humans, the US Environmental Protection Agency (EPA) and the National Toxicology Program (NTP) convened a committee to study the various biological effects that occur due to typical human exposure. After various experimental studies, the levels reported are as follows, the no-observedadverse-effects level (NOAEL) is $5.0 \mathrm{mg} / \mathrm{kg}$ body-weight/ day and the low-observed-adverse-effects level (LOAEL) is observed to be at $50 \mathrm{mg} / \mathrm{kg}$ body-weight/day. Therefore, consequently, the tolerable daily intake (TDI) of BPA was reported to be $4 \mu \mathrm{g} / \mathrm{kg}$ body-weight/day (Hong and Yang 2017).

\section{Metabolism and toxicity of BPA}

The primary organ responsible for the metabolism of BPA in humans is the liver. In the liver, phase II conjugation of BPA results in the transformation to mainly BPA-glucuronide (BPA-G) and small amounts of BPA-sulfate (BPA-S) conjugates (Fan et al. 2017). Uridine-5-diphospho-glucuronosyltransferases (UGTs) are the important class of enzymes involved in the catalysis of BPA glucuronidation that results in the transformation of BPA to BPA-G, and the main enzymes involved in the process are believed to be hepatic UGT2B15 and UGT1A9 (Hanioka et al. 2008). Furthermore, BPA is reported to be majorly excreted in the urine as glucuronide (94.6\%) (Provencher et al. 2014). The abnormalities in the functioning of UGTs enzyme cause the increase in levels of unconjugated BPA concentration in the system (Khan et al. 2021). Alongside, its ability to mimic the behavior of $17-\beta$ estradiol (Iso et al. 2006) results in the disruption of various pathways, causing moderately acute toxicity in humans. The most common pathological effects observed in laboratory studies with, and peer-reviewed human studies are obesity, cardiovascular diseases, hyperinsulinemia, thyroid, hypertension, ovarian and testicular developmental issues, PCOS, and cancer (Michałowicz 2014) (Fig. 1).

This review attempts to correlate the alteration in expression of various genes targeted by BPA and endocrine function in the pathophysiology of PCOS. It focuses on gene expression and endocrinal regulation in animal models and in vitro cultures of human cell lines, because of the limitations like 


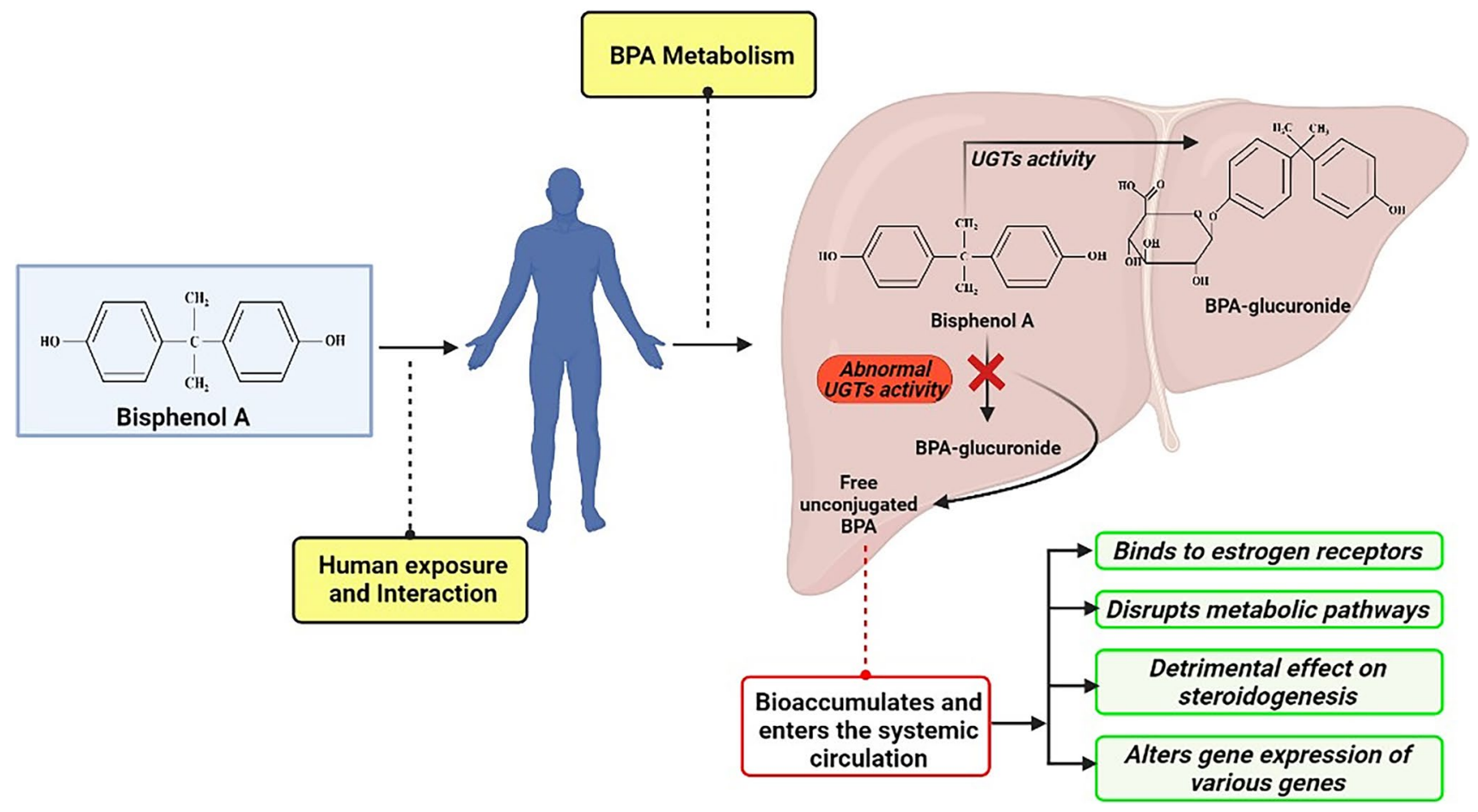

Fig. 1 Human exposure to BPA and its consequent metabolism

uncontrolled exposure, the impact of various other lifestyle factors, and the ethical constraint observed in human studies.

\section{Search strategies}

The search was conducted using PubMed as an electronic database. Studies were identified using the combination of the following search terms: "bisphenol A" AND "gene expression" OR "mRNA expression" OR "altered expression" OR "polycystic ovarian syndrome" OR "female reproductive system" OR "Insulin resistance" OR "Hyperandrogenism" OR "Ovulatory dysfunction" OR "estrous cyclicity" OR "Chronic inflammation" OR "steroidogenic hormones" OR "gonadotropins" OR "female sex hormones." All the data from both animal and in vitro studies on the relationship among BPA and the different aspects of the female reproductive and endocrine system, along with the clinical manifestation of PCOS were considered for inclusion. Furthermore, the information regarding mRNA expression, alteration of steroid hormone levels, BPA exposure, and PCOS were discussed in the review.

\section{Gene expression studies}

BPA has been observed to target and alter the gene expression of several important genes associated with PCOS, and their corresponding protein level dysregulation supports the observation (Table 1). Many observational studies have researched the alteration in gene expression by evaluating the levels of their transcribed mRNA, in various aspects like the disruption of the hypothalamic-pituitary-ovary (HPO) axis, disruption of steroidogenic and metabolic pathways and their results can be associated with the pathophysiology and manifestations of PCOS (Table 2).

\section{Gonadotropin dysregulation}

In female animals, the estrous cycle and in female humans the menstrual cycle is regulated by the interaction between hormones released by the hypothalamus, pituitary, and ovaries, thereby forming the HPO-axis. The pulsatile release of gonadotrophin-releasing hormone $(\mathrm{GnRH})$ from the hypothalamus, prompts the release of luteinizing hormone (LH) and follicle-stimulating hormone (FSH) from the anterior segment of the pituitary. These gonadotrophs in the ovarian level, act on ovarian follicles to release progesterone $(\mathrm{P})$ and estrogen (E). Estradiol (E2) is one of three estrogens produced, that regulates the release of LH and GnRH by a negative feedback action (Adachi et al. 2007) on binding with estrogen receptor $\alpha(E R \alpha)$ exhibited by kisspeptin neurons in the arcuate nucleus (ARC) and anteroventral periventricular nucleus (AVPV) (Kinoshita et al. 2005). E2 decreases the expression of KISS1 mRNA in ARC and increases KISS1 mRNA in AVPA, resulting in negative and positive feedback 
Table 1 List of genes targeted by BPA in the female reproductive system

\begin{tabular}{lll}
\hline Sl. no & Gene & Gene symbol \\
\hline 1 & Kisspeptin & KISS1 \\
& & \\
& & \\
2 & Gonadotropin releasing hormone 1 & $\begin{array}{l}\text { GNRH1 (humans) } \\
\text { Gnrh1 (mice) }\end{array}$ \\
3 & Gonadotropin releasing hormone 2 & GNRH2 (humans) \\
& & gnrh2 (fish) \\
4 & Resistin & RETN
\end{tabular}
Adiponectin

6 Leptin

7 Interleukin 6

Role Reference

Codes for the hypothalamic kisspeptin protein involved in the regulation of pubertal development and estrogen-mediated negative feedback of gonadotropin -releasing hormone

Dungan et al. (2006)

Codes for the preproprotein that generates peptides that stimulate the secretion of gonadotropins, i.e., luteinizing hormone (by GNRH1) and follicle-stimulating hormone

Codes for the preprotein of the Resistin hormone, which is an adipose-derived hormone that participates in an inflammatory response

Codes for a protein hormone involved in the regulation of glucose levels and the breakdown of fatty acids

Codes for an adipose-derived hormone that regulates appetite and fat storage in adipocytes

Codes for an interleukin that can be a pro-inflammatory cytokine and have an anti-inflammatory action in muscles

Codes for a pro-inflammatory cytokine that Ariemma et al. (2016) plays an important role in both innate and adaptive immunity, by stimulating the action of macrophages, natural killer cells, and neutrophils

Codes for a pro-inflammatory cytokine produced during inflammation by macrophages or monocytes, signal for cellular events that lead to necrosis or apoptosis

Codes for a protein that has a similar structure to Insulin and is responsible for growth stimulation in all cell types in adults

Codes. for a protein that has a similar structure to Insulin and is responsible for growth stimulation in all cell types in fetal development

$\operatorname{IGF1R}(R a$ and $R b) \quad$ Codes for a transmembrane receptor that belongs to the class of tyrosine kinase receptors and plays an important role in growth

Codes for ER $\alpha$ i.e., an estrogen receptor activated by estradiol that triggers cell proliferation in reproductive tissues and can translocate into the nuclease to regulate the activity of various genes by binding to the DNA

Codes for ER $\beta$ i.e., an estrogen receptor activated by estrogen that may inhibit cell proliferation in reproductive tissues and has the tumor-suppressing ability, by translocating into the nuclease and regulating the activity of various genes by binding to the DNA
Wang et al. (2014)

Qin et al. (2012)

Menale et al. (2017)

Menale et al. (2017)

Ariemma et al. (2016)

Ariemma et al. (2016)

Ariemma et al. (2016)

Aluru et al. (2010)

Aluru et al. (2010)

Aluru et al. (2010)

Wang et al. (2014)

Wang et al. (2014) 
Table 1 (continued)

\begin{tabular}{|c|c|c|c|c|}
\hline Sl. no & Gene & Gene symbol & Role & Reference \\
\hline 15 & $\begin{array}{l}\text { Luteinizing Hormone/Choriogonadotropin } \\
\text { Receptor }\end{array}$ & $L H C G R$ & $\begin{array}{l}\text { Codes for a receptor protein called the } \\
\text { luteinizing hormone/chorionic gon- } \\
\text { adotropin receptor, that as a receptor for } \\
\text { two ligands: luteinizing hormone and a } \\
\text { similar hormone called chorionic gon- } \\
\text { adotropin and allows the body to respond } \\
\text { appropriately to these hormones }\end{array}$ & Xi et al. (2011) \\
\hline 16 & Steroidogenic Acute Regulatory Protein & StAR & $\begin{array}{l}\text { Codes for a transport protein that regulates } \\
\text { cholesterol transfer within the mitochon- } \\
\text { dria }\end{array}$ & Zhou et al. (2008) \\
\hline 17 & Follicle Stimulating Hormone Receptor & FSHR & $\begin{array}{l}\text { Codes for a transmembrane receptor that } \\
\text { interacts with FSH }\end{array}$ & Xi et al. (2011) \\
\hline 18 & Follicle Stimulating Hormone subunit beta & $F S H B$ & $\begin{array}{l}\text { Codes for the } \beta \text {-subunit of FSH protein } \\
\text { that coupled with the common alpha } \\
\text { subunit form the FSH protein. With LH, } \\
\text { it induces egg and sperm production }\end{array}$ & Xi et al. (2011) \\
\hline 19 & Luteinizing Hormone subunit beta & $L H B$ & $\begin{array}{l}\text { Codes for the } \beta \text {-subunit of LH protein that } \\
\text { coupled with the common alpha subunit } \\
\text { from the LH protein. With FSH, it } \\
\text { induces egg and sperm production }\end{array}$ & Xi et al. (2011) \\
\hline 20 & $\begin{array}{l}\text { Cytochrome P450 Family } 11 \text { Subfamily A } \\
\text { Member } 1\end{array}$ & $C Y P 11 A 1$ & $\begin{array}{l}\text { Codes for the enzyme CYP450-side-chain } \\
\text { cleavage (p450scc), that catalyzes the } \\
\text { conversion of Cholesterol to Pregne- } \\
\text { nolone }\end{array}$ & Zhou et al. (2008) \\
\hline 21 & $\begin{array}{l}\text { Cytochrome P450 family } 19 \text { subfamily A } \\
\text { member } 1\end{array}$ & CYP19A1 & $\begin{array}{l}\text { Codes for Aromatase, the enzyme that } \\
\text { catalyzes the formation of estrogens from } \\
\text { androgens }\end{array}$ & Zhou et al. (2008) \\
\hline 22 & $\begin{array}{l}\text { Cytochrome P450 family } 17 \text { subfamily A } \\
\text { member } 1\end{array}$ & $C Y P 17 A 1$ & $\begin{array}{l}\text { Codes for p } 450 \mathrm{c} 17 \text { enzyme that both } \\
\text { hydroxylates pregnenolone at the } 17^{\text {th }} \\
\text { carbon and lysates } 21 \text {-carbon steroids to } \\
\text { 19-carbon steroids }\end{array}$ & Zhou et al. (2008) \\
\hline 23 & $\begin{array}{l}\text { Hydroxy-delta-5-steroid dehydrogenase, } 3 \\
\text { beta and steroid delta-isomerase } 1\end{array}$ & $H S D 3 B 1$ & $\begin{array}{l}\text { Codes for the isomerase, } 3 \\
\beta \text {-Hydroxysteroid dehydrogenase that is } \\
\text { responsible for the conversion of preg- } \\
\text { nenolone to progesterone and DHEA to } \\
\text { androstenedione, etc }\end{array}$ & Zhang et al. (2018) \\
\hline 24 & Anti-Mullerian hormone & $A M H$ & $\begin{array}{l}\text { Codes for the preprotein of Anti-Mullerian } \\
\text { hormone that inhibits the response of } \\
\text { granulosa cell to FSH and LH }\end{array}$ & Li et al. (2014) \\
\hline 25 & Estrogen Related Receptor Gamma & ESRRG & $\begin{array}{l}\text { Codes for a protein that binds to the estro- } \\
\text { gen response element and steroidogenic } \\
\text { factor } 1 \text { response element, to activate } \\
\text { genes controlled by them and has been } \\
\text { known to function as a transcriptional } \\
\text { activator of DNA cytosine-5-methyltrans- } \\
\text { ferases } 1 \text { (DNMT1) expression }\end{array}$ & Arase et al. (2011) \\
\hline 26 & Hydroxysteroid 17-beta dehydrogenase & $H S D 17 B(B 1, B 2, B 3)$ & $\begin{array}{l}\text { Codes for the isomerase, } 17 \\
\beta \text {-hydroxysteroid dehydrogenase that } \\
\text { regulate the levels of sex steroids by } \\
\text { reducing the C-17 hydroxy group of } \\
\text { androgens and estrogens }\end{array}$ & Shi et al. (2021) \\
\hline 27 & $\begin{array}{l}\text { Peroxisome proliferator-activated receptor } \\
\text { gamma }\end{array}$ & $P P A R G$ & $\begin{array}{l}\text { Codes for the protein PPAR- } \gamma \text { that activate } \\
\text { genes stimulating the uptake of lipids and } \\
\text { adipogenesis in fat cells, thereby regulat- } \\
\text { ing the storage of fatty acid and glucose } \\
\text { metabolism }\end{array}$ & Ariemma et al. (2016) \\
\hline
\end{tabular}


Table 1 (continued)

\begin{tabular}{|c|c|c|c|c|}
\hline Sl. no & Gene & Gene symbol & Role & Reference \\
\hline & Insulin & $I N S$ & $\begin{array}{l}\text { Codes for the hormone Insulin, which } \\
\text { controls the glucose levels in the blood } \\
\text { by regulating the metabolism of carbo- } \\
\text { hydrates and promoting the absorption } \\
\text { of glucose by the liver, adipocytes, and } \\
\text { skeletal muscle cells }\end{array}$ & Haq et al. (2020) \\
\hline
\end{tabular}

$E R \alpha$ estrogen receptor $\alpha, E R \beta$ estrogen receptor $\beta, F S H$ follicle-stimulating hormone, $L H$ luteinizing hormone, $D H E A$ dehydroepiandrosterone, $P P A R-\gamma$ peroxisome proliferator-activated receptor gamma

respectively (Dungan et al. 2006). As BPA possesses the ability to mimic the action of E2, it can bind to ER $\alpha$ (Fang et al. 2000), and thereby disrupt the functioning of the hypothalamus and pituitary gland. Also, the expression of genes like KISSI, GNRH, LHB, and FSHB has been subjected to alteration, as observed in various animal and in vitro studies when exposed to BPA.

The effects of BPA highly depend on the time of exposure, its duration, and dosage, hence having varying impacts on the result as observed in various studies. The dosedependent exposure of mouse embryonic hypothalamic cells to BPA for $3 \mathrm{~h}$, displayed significantly reduced expression of Gnrhl at $200 \mu \mathrm{M}$ when compared with control and other lower doses. The results suggested that Gnrhl expression in the cells was unresponsive to treatment below $200 \mu \mathrm{M}$ and its downregulation at high dose exposure results in disruption of maturation of the HPO-axis (Warita et al. 2013). The downregulation of the gene allows the hypothesis that high dose exposure to BPA incapacitates female rats from producing normal LH surges as seen in Wistar rats (Monje et al. 2010), since the gene codes for GnRH which stimulates the secretion of gonadotropins like LH and FSH from the pituitary gland.

On the other hand, neonatal exposure to BPA in female Sprague Dawley rats is seen to cause an upregulation of KISSI and GNRHI genes. Kisspeptin regulates the surge in gonadotropin levels during the initiation of female puberty and its activation by the neonatal BPA exposure shows that it can affect pubertal development (Qiu et al. 2020). This observation is also seen in a study conducted by $\mathrm{Xi}$ et al. (2011) on CD-1 mice, perinatal exposure to BPA causes upregulation of KISSI mRNA and GNRH mRNA in adults, which in turn causes alteration in the gene expression of gonadotropins $(F S H B, L H B)$ and their receptors $(F S H R$, $L H C G R$ ). As the feedback system is disturbed, these changes in the hypothalamus and pituitary can be both the cause and the consequence of the altered HPO-axis functioning.

The upregulation of ESRI (Wang et al. 2014) and ESR2 (Xi et al. 2011; Wang et al. 2014) mRNA in the pituitary exhibit a molecular basis of the selective action of BPA on the AVPV-kisspeptin neuron, which causes further upregulation of GNRH as observed in a study on ICR mice when exposed to $20 \mu \mathrm{g} / \mathrm{kg}$ body weight per day of BPA (Wang et al. 2014). The dose-dependent alteration in expression of GnRH is not only observed in mammals but also in teleost (Qin et al. 2012).

\section{Disrupted ovarian steroidogenesis and hyperandrogenism}

Ovarian steroidogenesis is a culmination of the interaction between LH, FSH, and enzymes like p450scc, p450c17, and aromatase. Androgen formation in ovarian theca cells is stimulated by LH and in granulosa cells, and biosynthesis of E2 from androgens is stimulated by FSH. StAR protein regulates the transfer of cholesterol into granulosa cells so that $\mathrm{p} 450 \mathrm{scc}$ can convert it to pregnanolone, which is then converted to progesterone by HSD-3 $\beta$ and simultaneously to androstenedione by the 17,20 -lyase activity of p450c17; furthermore, progesterone also gets converted to androstenedione in the theca cells. This androstenedione gets converted to estrone by aromatase and further to E2 by the activity of HSD-17 $\beta$ in granulosa cells (Hannon and Flaws 2015). The dysregulation of gene expression caused by BPA exposure, at the hypothalamus and pituitary level impacts the functioning of the ovary. The upregulation of $F S H B, L H B$ (Xi et al. 2011) FSHR, and LHCGR (Xi et al. 2011; Faheem et al. 2017) genes on high-dose BPA exposure and its consequent increase in stimulation of the ovarian follicles positively correlate it with the altered expression of genes coding for enzymes that participate in the conversion of androgens to E2 (Xi et al. 2011).

A study conducted by Zhou et al. (2008) on Sprague Dawley rats treated with varying doses of BPA exhibited upregulation of StAR, CYP11A1, and CYP17A1 in ovarian $\mathrm{T}-1$ cells. At a $10^{-4} \mathrm{M}$ dose of BPA, the increased expression of StAR and CYP11A1 may promote the production of more progesterone which paired with the upregulation of CYP17Al at $10^{-5} \mathrm{M}$ results in increased production of androgens. The sudden downregulation of CYP17A1 at $10^{-4} \mathrm{M}$ is assumed to be the result of cytotoxicity of granulosa cells from continuous testing (Zhou et al. 2008). The downregulation of CYP19A1 suggests that there is a decrease in the 
Table 2 Alteration in gene expression on BPA exposure

\begin{tabular}{|c|c|c|c|c|c|}
\hline Sl. no & Gene & Study model & Dosage of BPA & $\begin{array}{l}\text { Alteration in gene expres- } \\
\text { sion }\end{array}$ & Reference \\
\hline \multirow[t]{3}{*}{1} & \multirow[t]{3}{*}{ KISS1 } & $\begin{array}{l}\text { Female Sprague Dawley } \\
\text { rats }\end{array}$ & $\begin{array}{l}0.05,0.5 \mathrm{mg} \mathrm{kg}^{-1} \mathrm{day}^{-1} \\
10 \mathrm{mg} \mathrm{kg}^{-1} \mathrm{day}^{-1}\end{array}$ & $\begin{array}{l}\text { Downregulated } \\
\text { Upregulated }\end{array}$ & Qiu et al. (2020) \\
\hline & & ICR mice & $20 \mu \mathrm{g} \mathrm{kg}^{-1}$ day $^{-1}$ & $\begin{array}{l}\text { Upregulated (only in } \\
\text { AVPV) }\end{array}$ & Wang et al. (2014) \\
\hline & & CD-1 mice & $12,25,50 \mathrm{mg} \mathrm{kg}^{-1}$ day $^{-1}$ & Upregulated & Xi et al. (2011) \\
\hline \multirow[t]{6}{*}{2} & \multirow[t]{6}{*}{ GNRH1 } & ICR mice & $20 \mu \mathrm{g} \mathrm{kg}^{-1}$ day $^{-1}$ & Upregulated & Wang et al. (2014) \\
\hline & & $\begin{array}{l}\text { Embryonic mouse hypo- } \\
\text { thalamus cell line N44 } \\
\text { (mHypoE-N44) }\end{array}$ & $200 \mu \mathrm{M}$ & Downregulated & Warita et al. (2013) \\
\hline & & CD-1 mice & $12,25,50 \mathrm{mg} \mathrm{kg}^{-1}$ day $^{-1}$ & Upregulated & Xi et al. (2011) \\
\hline & & Wistar rats & $0.5 \mathrm{mg} \mathrm{kg}^{-1}$ & Upregulated & Monje et al. (2010) \\
\hline & & & $20 \mathrm{mg} \mathrm{kg}^{-1}$ & Downregulated & \\
\hline & & $\begin{array}{l}\text { Female Sprague Dawley } \\
\text { rats }\end{array}$ & $\begin{array}{l}0.05,0.5 \mathrm{mg} \mathrm{kg}^{-1} \mathrm{day}^{-1} \\
10 \mathrm{mg} \mathrm{kg}^{-1} \mathrm{day}^{-1}\end{array}$ & $\begin{array}{l}\text { Downregulated } \\
\text { Upregulated }\end{array}$ & (Qiu et al. (2020) \\
\hline 3 & GNRH2 & Gobiocypris rarus & $\begin{array}{l}5 \mu \mathrm{g} \mathrm{L}^{-1} \\
15 \mu \mathrm{g} \mathrm{L}^{-1}\end{array}$ & $\begin{array}{l}\text { Downregulated } \\
\text { Upregulated }\end{array}$ & Qin et al. (2012) \\
\hline 4 & RETN & $\begin{array}{l}\text { Human (In vitro culture of } \\
\text { differentiated adipocytes) }\end{array}$ & $1,10,100 \mathrm{nM}$ & Upregulated & Menale et al. (2017) \\
\hline \multirow[t]{4}{*}{5} & \multirow[t]{4}{*}{ Adipo $Q$} & $\begin{array}{l}\text { Human (In vitro culture of } \\
\text { differentiated adipocytes) }\end{array}$ & $\begin{array}{l}1 \mathrm{nM} \\
10,100 \mathrm{nM}\end{array}$ & $\begin{array}{l}\text { Upregulated } \\
\text { Downregulated }\end{array}$ & Menale et al. (2017) \\
\hline & & $\begin{array}{l}\text { Human (In vitro culture of } \\
\text { adipose tissue) }\end{array}$ & $10 \mathrm{nM}$ & Downregulated & Ahmed et al. (2020) \\
\hline & & $\begin{array}{l}\text { Mouse (In vitro culture of } \\
\text { 3T3-L1 pre-adipocytes) }\end{array}$ & $1 \mathrm{nM}$ & Upregulated & Ariemma et al. (2016) \\
\hline & & $\begin{array}{l}\text { Human (In vitro culture of } \\
\text { mature adipocytes and } \\
\text { SVF cells) }\end{array}$ & $0.1 \mathrm{nM}$ & Downregulated & Cimmino et al. (2019) \\
\hline \multirow[t]{2}{*}{6} & \multirow[t]{2}{*}{$L E P$} & $\begin{array}{l}\text { Mouse (In vitro culture of } \\
\text { 3T3-L1 pre-adipocytes) }\end{array}$ & $1 \mathrm{nM}$ & Upregulated & Ariemma et al. (2016) \\
\hline & & $\begin{array}{l}\text { Human (In vitro culture of } \\
\text { mature adipocytes and } \\
\text { SVF cells) }\end{array}$ & $0.1 \mathrm{nM}$ & Upregulated & Cimmino et al. (2019) \\
\hline \multirow[t]{3}{*}{7} & \multirow[t]{3}{*}{ IL6 } & $\begin{array}{l}\text { Mouse (In vitro culture of } \\
\text { 3T3-L1 pre-adipocytes) }\end{array}$ & $1 \mathrm{nM}$ & Upregulated & Ariemma et al. (2016) \\
\hline & & $\begin{array}{l}\text { Human (In vitro culture of } \\
\text { adipose tissue) }\end{array}$ & $10,10^{4} \mathrm{nM}$ & Downregulated & Ahmed et al. (2020) \\
\hline & & $\begin{array}{l}\text { Human (In vitro culture of } \\
\text { mature adipocytes and } \\
\text { SVF cells) }\end{array}$ & $0.1 \mathrm{nM}$ & Upregulated & Cimmino et al. (2019) \\
\hline \multirow[t]{2}{*}{8} & \multirow[t]{2}{*}{$I F N G$} & $\begin{array}{l}\text { Mouse (In vitro culture of } \\
\text { 3T3-L1 pre-adipocytes) }\end{array}$ & $1 \mathrm{nM}$ & Upregulated & Ariemma et al. (2016) \\
\hline & & F344 rats & $4,40,400 \mathrm{mg} \mathrm{kg}^{-1}$ day $^{-1}$ & Downregulated & Miao et al. (2008) \\
\hline \multirow[t]{3}{*}{9} & \multirow[t]{3}{*}{$T N F A$} & F344 rats & $4,40,400 \mathrm{mg} \mathrm{kg}^{-1}$ day $^{-1}$ & Downregulated & Miao et al. (2008) \\
\hline & & $\begin{array}{l}\text { Human (In vitro culture of } \\
\text { adipose tissue) }\end{array}$ & $1 \mathrm{nM}$ & Downregulated & Ahmed et al. (2020) \\
\hline & & $\begin{array}{c}\text { Mouse (In vitro culture of } \\
\text { 3T3-L1 pre-adipocytes) }\end{array}$ & $1 \mathrm{nM}$ & Upregulated & Ariemma et al. (2016) \\
\hline 10 & $I G F 1$ & $\begin{array}{l}\text { Oncorhynchus mykiss } \\
\text { (oocytes) }\end{array}$ & $30,100 \mu \mathrm{g} \mathrm{mL}^{-1}$ & Downregulated & Aluru et al. (2010) \\
\hline 11 & $I G F 2$ & $\begin{array}{l}\text { Oncorhynchus mykiss } \\
\text { (oocytes) }\end{array}$ & $30,100 \mu \mathrm{g} \mathrm{mL}^{-1}$ & Downregulated & Aluru et al. (2010) \\
\hline
\end{tabular}


Table 2 (continued)

\begin{tabular}{|c|c|c|c|c|c|}
\hline S1. no & Gene & Study model & Dosage of BPA & $\begin{array}{l}\text { Alteration in gene expres- } \\
\text { sion }\end{array}$ & Reference \\
\hline \multirow[t]{2}{*}{12} & \multirow[t]{2}{*}{$\operatorname{IGF1R}(R a$ and $R b)$} & $\begin{array}{l}\text { Oncorhynchus mykiss } \\
\text { (oocytes) }\end{array}$ & $30,100 \mu \mathrm{g} \mathrm{mL}^{-1}$ & Downregulated & Aluru et al. (2010) \\
\hline & & $\begin{array}{l}\text { Human (BG-1 ovarian } \\
\text { adenocarcinoma cell line) }\end{array}$ & $10^{-5} \mathrm{M}$ & Upregulated & Kang et al. (2013) \\
\hline \multirow[t]{4}{*}{13} & \multirow[t]{4}{*}{ ESRl } & ICR mice & $20 \mu \mathrm{g} \mathrm{kg}^{-1}$ day $^{-1}$ & Upregulated & Wang et al. (2014) \\
\hline & & $\begin{array}{l}\text { Human (BG-1 ovarian } \\
\text { adenocarcinoma cell line) }\end{array}$ & $10^{-5} \mathrm{M}$ & Upregulated & Kang et al. (2013) \\
\hline & & F344 rats & 4, 40, $400 \mathrm{mg} \mathrm{kg}^{-1} \mathrm{day}^{-1}$ & Upregulated & Miao et al. (2008) \\
\hline & & Gobiocypris rarus & $15 \mu \mathrm{g} \mathrm{L}^{-1}$ & Downregulated & Zhang et al. (2018) \\
\hline \multirow[t]{3}{*}{14} & \multirow[t]{3}{*}{ ESR2 } & ICR mice & $20 \mu \mathrm{g} \mathrm{kg}^{-1}$ day $^{-1}$ & Upregulated & Wang et al. (2014) \\
\hline & & CD-1 mice & $12,25,50 \mathrm{mg} \mathrm{kg}^{-1}$ day $^{-1}$ & Upregulated & Xi et al. (2011) \\
\hline & & Gobiocypris rarus & $15 \mu \mathrm{g} \mathrm{L}-1$ & $\begin{array}{l}\text { ESR2 } \alpha \text {-No effects } \\
\text { ESR2 } \beta \text { - Upregulated }\end{array}$ & Zhang et al. (2018) \\
\hline \multirow[t]{4}{*}{15} & \multirow[t]{4}{*}{$L H C G R$} & $\begin{array}{l}\text { Zebrafish ovarian follicle } \\
\text { cells }\end{array}$ & $5 \mu \mathrm{M}$ & Upregulated & Liu et al. (2013) \\
\hline & & CD-1 mice & $12 \mathrm{mg} \mathrm{kg}^{-1}$ day $^{-1}$ & Downregulated & Xi et al. (2011) \\
\hline & & & $25,50 \mathrm{mg} \mathrm{kg}^{-1}$ day $^{-1}$ & Upregulated & \\
\hline & & Catla catla (ovary tissue) & $10,100,1000 \mu \mathrm{g} \mathrm{L}^{-1}$ & Upregulated & Faheem et al. (2017) \\
\hline \multirow[t]{8}{*}{16} & \multirow[t]{8}{*}{ StAR } & CD-1 mice & $\begin{array}{l}12,50 \mathrm{mg} \mathrm{kg}^{-1} \mathrm{day}^{-1} \\
25 \mathrm{mg} \mathrm{kg}^{-1} \mathrm{day}^{-1}\end{array}$ & $\begin{array}{l}\text { Upregulated } \\
\text { Downregulated }\end{array}$ & Xi et al. (2011) \\
\hline & & $\begin{array}{l}\text { Human (In vitro culture of } \\
\text { ovarian granulosa KGN } \\
\text { cells) }\end{array}$ & $0.5,5,50,500 \mu \mathrm{g} \mathrm{L}^{-1}$ & Downregulated & Shi et al. (2021) \\
\hline & & Catla catla (ovary tissue) & $10,100,1000 \mu \mathrm{g} \mathrm{L}^{-1}$ & Upregulated & Faheem et al. (2017) \\
\hline & & Gobiocypris rarus & $15 \mu g \mathrm{~L}^{-1}$ & Downregulated & Zhang et al. (2018) \\
\hline & & CD-1 mice (antral follicles) & $10,100 \mu \mathrm{g} \mathrm{mL}^{-1}$ & Downregulated & Peretz and Flaws (2013) \\
\hline & & Wistar rats (In vitro culture & $0.1,1,10 \mu \mathrm{M}$ & Downregulated & Samardzija et al. (2018) \\
\hline & & of granulosa cells) & $50,100 \mu \mathrm{M}$ & Upregulated & \\
\hline & & & $10^{-4} \mathrm{M}$ & Upregulated & Zhou et al. (2008) \\
\hline \multirow[t]{3}{*}{17} & \multirow[t]{3}{*}{ FSHR } & CD-1 mice & $12 \mathrm{mg} \mathrm{kg}^{-1}$ day $^{-1}$ & Downregulated & Xi et al. (2011) \\
\hline & & & $25,50 \mathrm{mg} \mathrm{kg}^{-1}$ day $^{-1}$ & Upregulated & \\
\hline & & Catla catla (ovary tissue) & $10,100,1000 \mu \mathrm{g} \mathrm{L}^{-1}$ & Upregulated & Faheem et al. (2017) \\
\hline 18 & $F S H B$ & CD-1 mice & $12,25,50 \mathrm{mg} \mathrm{kg}^{-1}$ day $^{-1}$ & Upregulated & Xi et al. (2011) \\
\hline 19 & $L H B$ & CD-1 mice & $\begin{array}{l}12,25 \mathrm{mg} \mathrm{kg}^{-1} \mathrm{day}^{-1} \\
50 \mathrm{mg} \mathrm{kg}^{-1} \mathrm{day}^{-1}\end{array}$ & $\begin{array}{l}\text { Upregulated } \\
\text { Downregulated }\end{array}$ & Xi et al. (2011) \\
\hline \multirow[t]{6}{*}{20} & \multirow[t]{6}{*}{ CYP11A1 } & CD-1 mice & $12,25,50 \mathrm{mg} \mathrm{kg}^{-1}$ day $^{-1}$ & Upregulated & Xi et al. (2011) \\
\hline & & CD-1 mice (antral follicles) & $10,100 \mu \mathrm{g} \mathrm{mL}^{-1}$ & Downregulated & Peretz and Flaws (2013) \\
\hline & & Sprague Dawley rat (ovary) & $\begin{array}{l}10^{-4} \mathrm{M} \\
10^{-5} \mathrm{M}\end{array}$ & $\begin{array}{l}\text { Downregulated } \\
\text { Upregulated }\end{array}$ & Zhou et al. (2008) \\
\hline & & Mouse urogenital sinus & $20 \mu \mathrm{g} \mathrm{kg}^{-1}$ & Upregulated & Arase et al. (2011) \\
\hline & & $\begin{array}{l}\text { Wistar rats (In vitro culture } \\
\text { of granulosa cells) }\end{array}$ & $100 \mu \mathrm{M}$ & Upregulated & Samardzija et al. (2018) \\
\hline & & $\begin{array}{l}\text { Human (placental JEG-3 } \\
\text { cell lines) }\end{array}$ & $1-1000 \mathrm{nM}$ & Downregulated & Chu et al. (2018) \\
\hline
\end{tabular}


Table 2 (continued)

\begin{tabular}{|c|c|c|c|c|c|}
\hline Sl. no & Gene & Study model & Dosage of BPA & $\begin{array}{l}\text { Alteration in gene expres- } \\
\text { sion }\end{array}$ & Reference \\
\hline \multirow[t]{8}{*}{21} & \multirow[t]{8}{*}{ CYP19A1 } & CD-1 mice & $12,25,50 \mathrm{mg} \mathrm{kg}^{-1}$ day $^{-1}$ & Upregulated & Xi et al. (2011) \\
\hline & & $\begin{array}{l}\text { Human (In vitro culture of } \\
\text { ovarian granulosa KGN } \\
\text { cells) }\end{array}$ & $0.5,5,50,500 \mu \mathrm{g} \mathrm{L}-1$ & Upregulated & Shi et al. (2021) \\
\hline & & Catla catla (ovary tissue) & $10,100,1000 \mu \mathrm{g} \mathrm{L}^{-1}$ & Upregulated & Faheem et al. (2017) \\
\hline & & Sprague Dawley rat (ovary) & $10^{-4} 10^{-6} \mathrm{M}$ & Downregulated & Zhou et al. (2008) \\
\hline & & Mouse urogenital sinus & $20 \mu \mathrm{g} \mathrm{kg}^{-1}$ & Upregulated & Arase et al. (2011) \\
\hline & & $\begin{array}{l}\text { Human (placental JEG-3 } \\
\text { cell lines) }\end{array}$ & $11000 \mathrm{nM}$ & Downregulated & Chu et al. (2018) \\
\hline & & $\begin{array}{l}\text { Human (ovarian granulosa- } \\
\text { like (KGN) cell lines) }\end{array}$ & $50 \mu \mathrm{M}$ & Downregulated & Watanabe et al. (2012) \\
\hline & & Gobiocypris rarus & $5,15 \mu \mathrm{g} \mathrm{L}-1$ & Downregulated & Qin et al. (2012) \\
\hline \multirow[t]{4}{*}{22} & \multirow[t]{4}{*}{ CYP17A1 } & CD-1 mice & $12,25 \mathrm{mg} \mathrm{kg}^{-1} \mathrm{day}^{-1}$ & Downregulated & Xi et al. (2011) \\
\hline & & & $50 \mathrm{mg} \mathrm{kg}^{-1}$ day $^{-1}$ & Upregulated & \\
\hline & & Sprague Dawley rat (ovary) & $10^{-4} \mathrm{M}$ & Upregulated & Zhou et al. (2008) \\
\hline & & Gobiocypris rarus & $13.75 \pm 1.63 \mu \mathrm{g} \mathrm{L}^{-1}$ & Downregulated & Zhang et al. (2017) \\
\hline \multirow[t]{2}{*}{23} & \multirow[t]{2}{*}{$H S D 3 B 1$} & Gobiocypris rarus & $15 \mu \mathrm{g} \mathrm{L}^{-1}$ & Upregulated & Zhang et al. (2018) \\
\hline & & $\begin{array}{l}\text { Wistar rats (In vitro culture } \\
\text { of granulosa cells) }\end{array}$ & $100 \mu \mathrm{M}$ & Upregulated & Samardzija et al. (2018) \\
\hline \multirow[t]{2}{*}{24} & \multirow[t]{2}{*}{$A M H$} & Mice & $10,40,60 \mathrm{mg} \mathrm{kg}^{-1}$ & Upregulated & Li et al. (2014) \\
\hline & & Mice & $5,50,500 \mu \mathrm{g} \mathrm{kg}^{-1}$ & Downregulated & Cao et al. (2018) \\
\hline 25 & $E S R R G$ & Mouse urogenital sinus & $20 \mu \mathrm{g} \mathrm{kg}^{-1}$ & Upregulated & Arase et al. (2011) \\
\hline 26 & $H S D 17 B(B 1, B 2, B 3)$ & $\begin{array}{l}\text { Human (In vitro culture of } \\
\text { ovarian granulosa KGN } \\
\text { cells) }\end{array}$ & $0.5,5,50,500 \mu \mathrm{g} \mathrm{L}^{-1}$ & Downregulated & Shi et al. (2021) \\
\hline 27 & PPARG & $\begin{array}{l}\text { Mouse (In vitro culture of } \\
\text { 3T3-L1 pre-adipocytes) }\end{array}$ & $1 \mathrm{nM}$ & Upregulated & Ariemma et al. (2016) \\
\hline 28 & INS & Wistar rats & $50,500,2500,5000 \mu \mathrm{g} \mathrm{kg}^{-1}$ & Upregulated & Haq et al. (2020) \\
\hline
\end{tabular}

KISS1 Kisspeptin, GNRH1 gonadotropin-releasing hormone 1, GNRH2 gonadotropin-releasing hormone 2, RETN resistin, AdipoQ adiponectin, $L E P$ leptin, IL-6 interleukin 6, IFNG interferon gamma, TNFA tumor necrosis factor-alpha, IGF1 insulin-like growth factor 1 , IGF2 insulin-like growth factor 2, IGF1R insulin-like growth factor 1 receptor, ESR1 estrogen receptor 1, ESR2 estrogen receptor 2, LHCGR luteinizing hormone/choriogonadotropin receptor, StAR steroidogenic acute regulatory protein, FSHR follicle-stimulating hormone receptor, FSHB follicle-stimulating hormone subunit beta, $L H B$ luteinizing hormone subunit beta, CYP11A1 cytochrome P450 family 11 subfamily A member 1, CYP19A1 cytochrome P450 family 19 subfamily A member 1, CYP17A1 cytochrome P450 family 17 subfamily A member 1 , HSD3B1 hydroxy-delta-5-steroid dehydrogenase, 3 beta and steroid delta-isomerase 1, AMH anti-Mullerian hormone, ESRRG estrogen-related receptor gamma, $H S D 17 B$ hydroxysteroid 17-beta dehydrogenase, $P P A R G$ peroxisome proliferator-activated receptor gamma, INS insulin, $\mu \mathrm{g}$ microgram, $\mathrm{kg}$ kilogram, mg milligram, $\mu \mathrm{M}$ micromolar, $\mathrm{nM}$ nanomolar, $\mathrm{L}$ litre, $\mathrm{mL}$ mililiter, $\mathrm{M}$ molar

conversion of androgen to E2, on exposure to BPA (Xi et al. 2011; Chu et al. 2018; Watanabe et al. 2012). On exposure to BPA, the upregulation of HSD3B1 (Wang et al. 2014; Samardzija et al. 2018) and downregulation of $H S D 17 B$ gene (Shi et al. 2021) further consolidate the chances of increased androgen levels, as there is a possible increase in conversion of progesterone to androgens and androstenedione to E2, respectively.

Furthermore, BPA exposure has also been observed to upregulate the genes encoding orphan nuclear receptors like estrogen-related receptor- $\gamma($ ESRR- $\gamma)($ Arase et al. 2011), thereby suggesting that BPA can participate in an orphan nuclear receptor-mediated alteration of the expression of steroidogenic enzymes in the ovary (Xi et al. 2011). The contradicting and differing results of alteration in gene expression could be credited to the difference in cell types and organisms under study, their dosage, and time of dosage. The disruption caused by BPA in the expression of genes participating in ovarian steroidogenesis could cause hyperandrogenism and ovulatory dysfunction (Rutkowska and Rachoń 2014). 


\section{Ovarian folliculogenesis disruption}

The dysregulation of gonadotropin secretion and its consequent disruption of the HPO-axis contribute to ovarian follicular arrest and major changes in the morphology and functioning of the ovary. The upregulation of $L H B$ (Xi et al. 2011) may contribute to the hypertrophy of ovarian follicles thereby leading to their premature luteinization (Azziz et al. 2016). It is observed that on pre-pubertal exposure to high doses of BPA, the expression of $A M H$ increases in ovarian granulosa cells. The upregulation of $A M H$ can be contributed to the effect of BPA in increased numbers of small antral follicles in comparison to the overall numbers of follicles present in the ovary ( $\mathrm{Li}$ et al. 2014). This could lead to a decrease in FSH sensitivity, which could further impair follicular growth (Gruijters et al. 2003).

Whereas exposure to low doses of BPA shows downregulation of the $A M H$ gene, this result is hypothesized to be caused by the effect of BPA on the reduction of granulosa cell activity and its subsequent accelerated apoptosis (Cao et al. 2018). Another possible factor could be the downregulation of $I G F 1, I G F 2$, and $I G F 1 R$ genes on perinatal BPA exposure, which tends to result in the lack of development of ovarian cells and suppresses growth in general (Aluru et al. 2010).

\section{Adipose tissue dysfunction, insulin resistance, and chronic inflammation}

Adipose tissue acts not only as a fat storage reservoir that participates in homeostasis but also as an endocrine organ that secretes regulatory adipokines, cytokines, and chemokines. BPA is known to disrupt various metabolic pathways such as lipid metabolism, carbohydrate metabolism, insulin signaling pathway, and cause adipose tissue inflammation. A study conducted by Ariemma et al. (2016) observed the various effects of prolonged low dose exposure of BPA on adipocyte differentiation. BPA exposure tends to increase pre-adipocyte growth by upregulation of $P P A R G$, Adipo $Q$, and $L E P$ genes that regulate adipogenesis and paired with the proinflammatory action of BPA; this exacerbates insulin sensitivity in adipocytes and hampers the insulin signaling pathway (Ariemma et al. 2016). It is observed that the regulation of glucose level on BPA exposure compensates for the upregulation of the INSI gene (Haq et al. 2020). On exposure to BPA, the upregulation of $L E P$ (Ariemma et al. 2016; Cimmino et al. 2019) in cultures of adipocytes displays a possibility of an increase in fat storage, thereby drawing a correlation between BPA exposure and obesity.
Furthermore, the dose-dependent downregulation of Adipo $Q$ mRNA in in vitro cultures of adipocytes (Cimmino et al. 2019; Menale et al. 2017; Ahmed et al. 2020) suggests the dysregulation in the breakdown of fatty acids and desensitization of cells to insulin. This combined with the upregulation of RETN (Menale et al. 2017) inhibits insulin action and presents a possible link between BPA exposure causing obesity and insulin resistance. As adipose tissue insulin resistance is intricately linked to increased inflammation, the alteration in expression of inflammatory cytokines such as IL6 (Ariemma et al. 2016; Cimmino et al. 2019; Ahmed et al. 2020), IFNG (Ariemma et al. 2016; Miao et al. 2008), TNFA (Miao et al. 2008) that are adipose-derived confirms the effect of BPA exposure leading to chronic inflammation in adipocytes may cause insulin resistance.

\section{Hormonal changes caused by BPA}

The alteration in the expression of hormone-coding genes and enzymes brings about biochemical changes in hormone and enzyme levels. Since BPA can have post-translational effects on the expression of proteins, it is important to corroborate the results of gene expression with protein expression (Table 3).

The study conducted by Zhou et al. (2008) on female Sprague Dawley rats showed elevated levels of testosterone and progesterone, along with reduced levels of estradiol. The levels are a result of the altered gene expression of steroidogenic enzymes-StAR, p450scc, p450c17, and aromatase in the ovary on BPA exposure (Zhou et al. 2008). This supports the hypothesis that BPA exposure can cause hyperandrogenism. As the increased androgen levels activate a pro-inflammatory condition, there is a development of a pro-oxidant state in the ovaries; this, in turn, accelerates cellular apoptosis. And the hampered cellular activity due to repeated exposure of granulosa cells to low doses of BPA causes a decrease in Anti-Mullerian hormone (AMH) and estradiol levels in ovarian follicles. This could in turn lead to a decrease in ovarian reserve as it hampers the number of raised follicles and the quality of mature oocytes (Cao et al. 2018). However, the effect of BPA on the expression of $A M H$ has been observed to vary with the stage of development. In the pre-pubertal period, increased levels of AMH and decreased number of corpus luteum result in a significant decrease in serum levels of P4, displaying a disruption in follicular development ( $\mathrm{Li}$ et al. 2014).

The dysregulated functioning of the HPO-axis plays a major role in the underlying mechanism of altered hormone levels and ovarian morphology. The increased GnRH pulsatility and reduced GnRH-induced LH levels (Fernández et al. 2009) on high-dose BPA exposure further result in the 


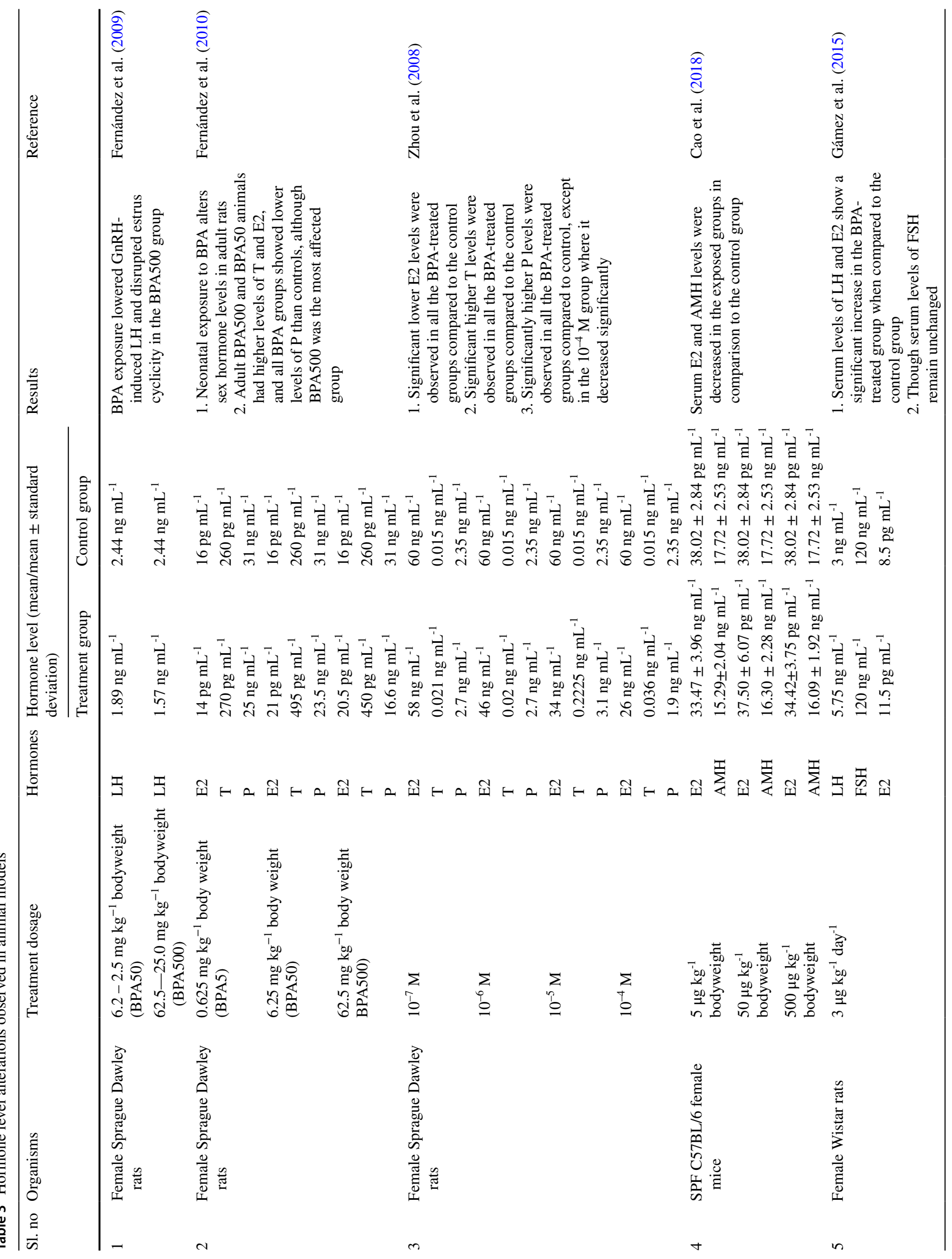




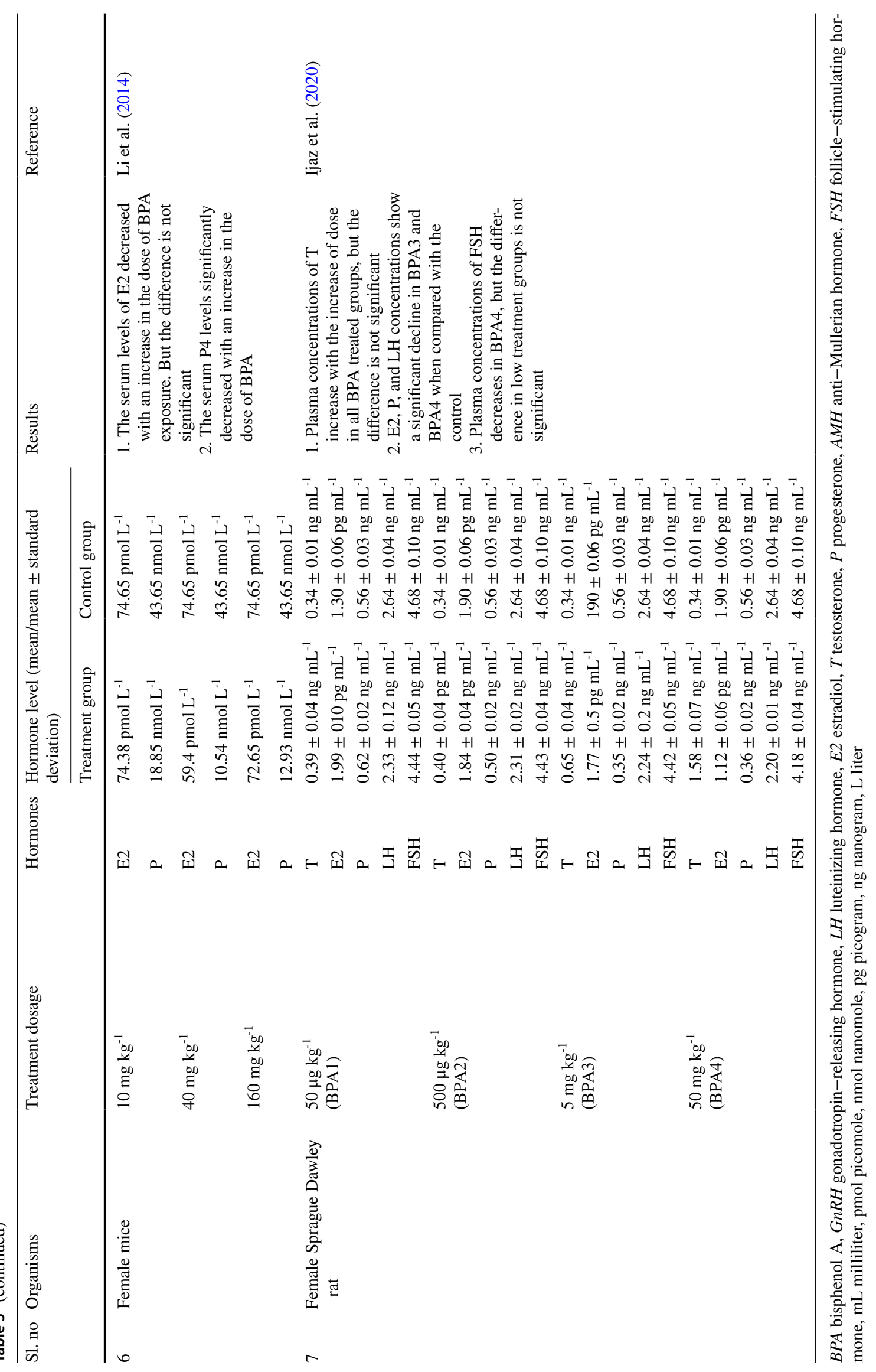


alteration of sex hormone levels where serum Testosterone (T) and E2 levels are increased, and P levels are decreased (Fernández et al. 2010). This correlates the effects of BPA exposure to the altered hypothalamic-pituitary functioning as observed in PCOS.

A study conducted by Gámez et al. (2015) observes increased LH and E2 levels; this contradicts the previous results, and this can be attributed to the difference in BPA dosage and the time of exposure. Other than hyperandrogenism, BPA too has been observed to have the potential to induce oxidative stress that may affect the alteration in hormone levels (increase in T; decrease in E2, P, LH, and FSH) because of the impaired HPO-axis functioning and altered histopathology of the ovary (Ijaz et al. 2020).

\section{Ovarian morphological changes caused by BPA}

As discussed in the previous sections, BPA has a mild estrogenic activity similar to $\mathrm{E} 2$ and possesses the ability to disrupt the HPO-axis. This disruption causes clinical manifestations in the form of hormonal imbalance and subsequent alteration in ovarian morphology. Various studies that focus on this aspect are summarized in Table 4.

A dose-dependent decrease in oocytes is observed with an increase in the dose of BPA exposure because of oocyte apoptosis (Fernández et al. 2010). This in turn shows lowered development of primordial follicles on exposure to high doses of BPA (Zhu et al. 2018). On BPA exposure the alteration in expression of ESR 1 and ESR 2 in ovarian follicles causes an increase in follicular recruitment (Rodríguez et al. 2010), thereby resulting in the observation of increased numbers of preovulatory follicles (Fernández et al. 2010; Ijaz et al. 2020), primary follicles (Gámez et al. 2015), and secondary follicles (Gámez et al. 2015). It has been observed that BPA alters follicular growth and induces atresia, thereby leading to observations of increased atretic follicles (Fernández et al. 2010; Gámez et al. 2015; Ijaz et al. 2020) on exposure to high doses. This in turn leads to decreased number of antral follicles (Fernández et al. 2010; Gámez et al. 2015; Ijaz et al. 2020; Zhu et al. 2018), hence increasing rates of follicular arrest that leads to anovulation (Rutkowska and Rachon 2014). As the BPA-exposed animals exhibit reduced LH secretion because of the irregular GnRH pulsatility (Fernández et al. 2009), its ability to cause cell enlargement and production of P may decrease (Azziz et al. 2016), and this paired with low numbers of antral follicles that may mature leads to a significant decrease in the number of corpus luteum observed (Fernández et al. 2010; Ijaz et al. 2020; Zhu et al. 2018; Adewale et al. 2009).

A study conducted by Qiu et al. (2020) observes normal ovarian morphology and follicular development, in adult rats that were neonatally exposed to BPA. Since the time of exposure plays a huge role in the development of effects, this could contribute to the difference in results (Qiu et al. 2020).

\section{Effect of BPA on PCOS}

The effect of BPA on pathways like insulin signaling, lipid metabolism, ovarian steroidogenesis, and the functioning of the HPO-axis is well observed in animal models and in vitro human cell line studies. The results obtained can be correlated with the findings in various human epidemiology studies. These studies focus on the relationship between BPA and the factors crucial in the clinical manifestation and pathogenesis of PCOS, by establishing a correlation between the presence of BPA and the altered levels of hormone levels in PCOS patients.

BPA has been observed to cause disruptions in several metabolic pathways and functioning of the endocrine system, thereby giving rise to PCOS in premenopausal women. Since BPA mimics the activity of $17-\beta$ estradiol, it has been reported to possess the ability to disrupt steroid feedbacks at the hypothalamus-pituitary level and steroid action at the ovarian level, thereby suppressing HPO-axis functions (Wang et al. 2017). This includes hypersecretion of circulating $\mathrm{LH}$ and increased levels of FSH, causing alteration of LH:FSH ratios (Vahedi et al. 2016).

In addition, BPA contributes to the disarrayed metabolic profile in PCOS due to the involvement of BPA in insulin resistance (Kandaraki et al. 2011) and its promotion of inflammatory conditions through the development of obesity and infiltration of macrophages into the adipose tissue (Tarantino et al. 2013). Chronic inflammation aids the development of insulin resistance, and the subsequent compensatory hyperinsulinemia indirectly leads to increased amplitude and frequency of GnRH and LH pulse secretion observed in PCOS. This increase also induces relative resistance of follicles to FSH and subsequent increase in production of $\mathrm{AMH}$, promoting a decrease in antral follicle count thereby plausibly impairing the ovarian reserve (Zhou et al. 2017). Furthermore, BPA exposure causes attenuation of aromatase expression in the follicular fluid causing dysregulation in estrogen production (Wang et al. 2017). This paired with the potential of BPA to increase androgen levels due to its inhibitory effect on the action of testosterone-hydroxylase (Takeuchi et al. 2006) has the ability to cause hyperandrogenism (Jurewicz et al. 2021).

Moreover, a prospective observational study conducted by Déchaud et al. (1999) suggests that an increase in free testosterone levels in the serum is because of the ability of BPA to displace sex steroid hormones from SHBG. In association with these findings, it appears that in PCOS the metabolism and excretion of BPA are impaired due to the 


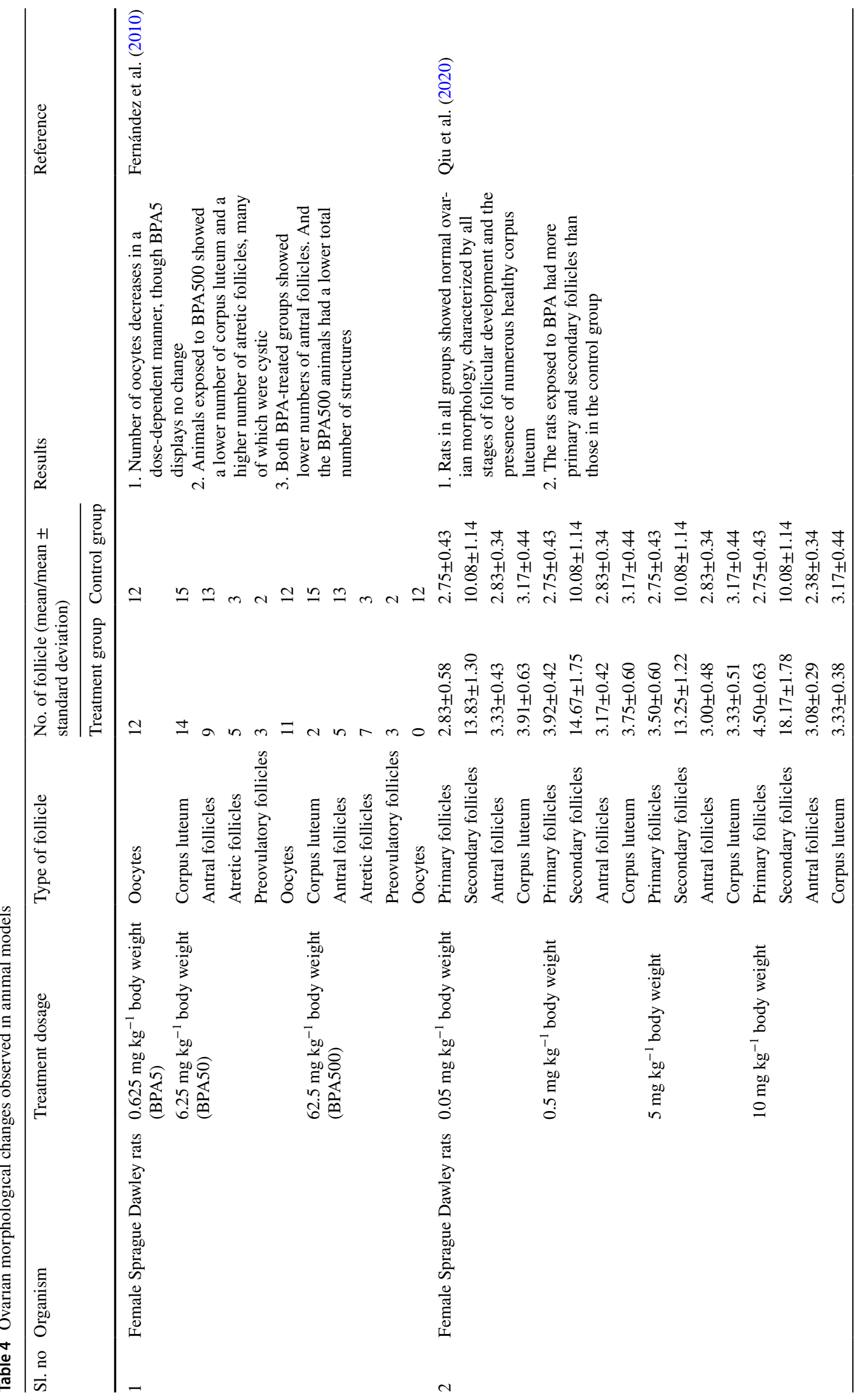




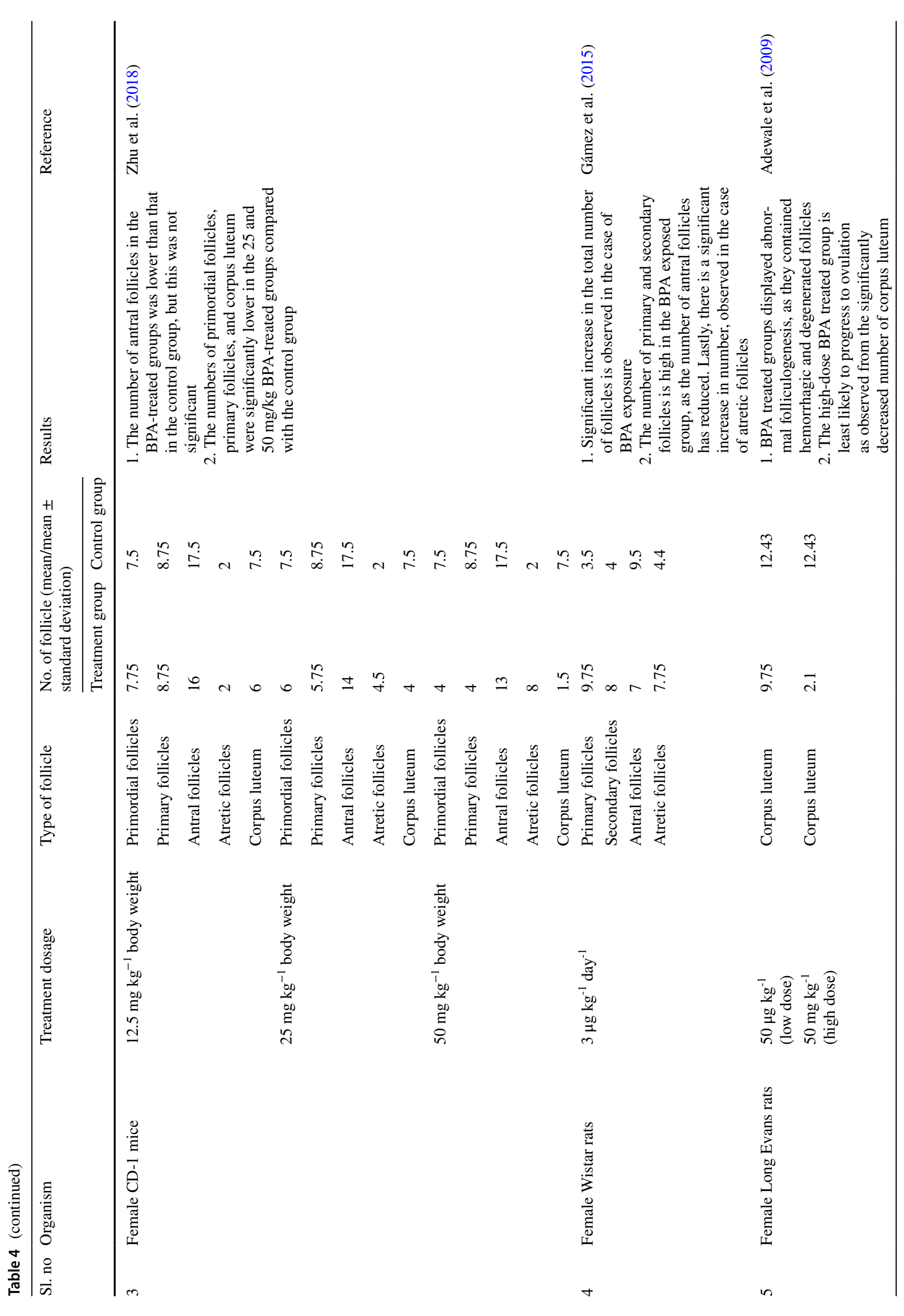




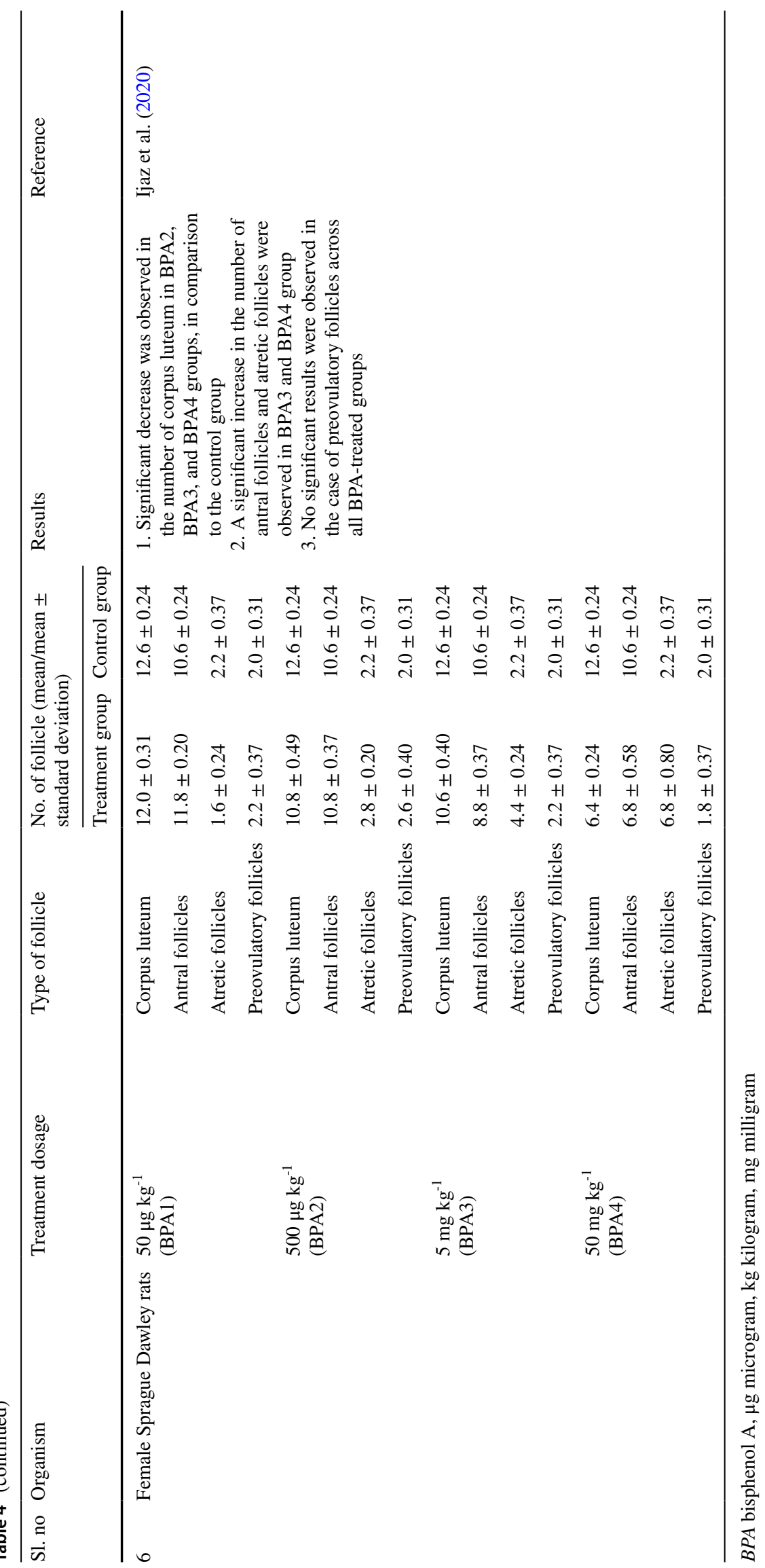




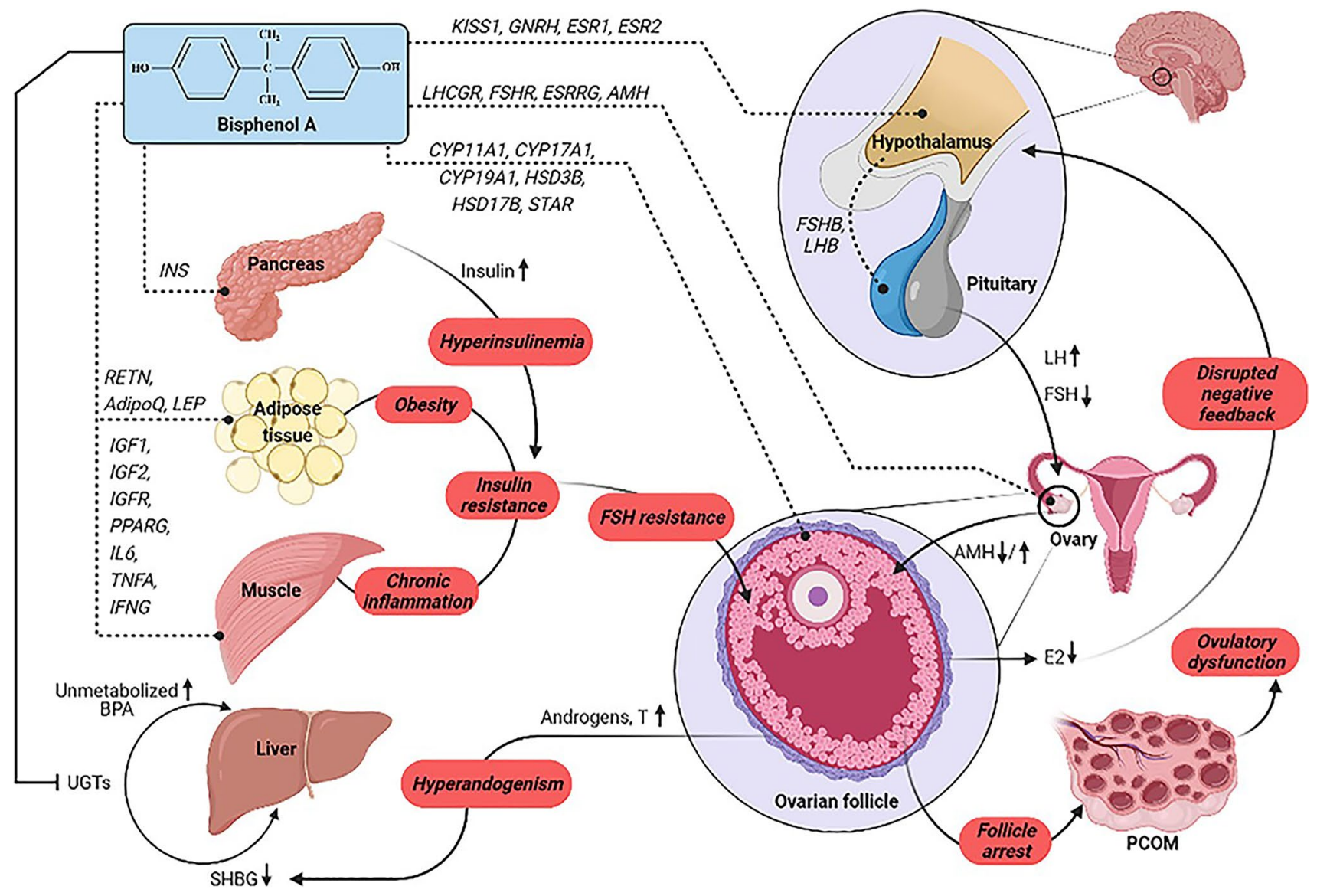

Fig. 2 The effect of BPA on the expression of certain genes involved in the PCOS pathogenesis

effect of hyperandrogenism in blocking the expression of uridine diphosphate-glucuronosyl transferase (UGTs) that completely metabolizes BPA (Vermeulen 1993). The resulting effects are well studied by Takeuchi et al. (2004) in a case-controlled study that indicates increased BPA levels in women diagnosed with PCOS. Despite BPA having a short half-life, it has an inhibitory effect on the activity of UGT, which causes BPA to remain incompletely metabolized thereby increasing its levels in the body. This causes an alteration in gene expression that disturbs various endocrinal processes like gonadotropin secretion and receptivity, ovarian steroidogenesis, insulin activity, and regulation of adipokines, which in turn causes demonstration of clinical manifestations like ovulatory dysfunction, disrupted folliculogenesis, polycystic ovarian morphology, hyperandrogenism, hyperinsulinemia, obesity that are associated with PCOS (Fig. 2).

All these results compiled suggest that the presence of BPA in women with PCOS could be both a cause and consequence of disrupted hormonal patterns and metabolic activity that result in clinical manifestations like hyperandrogenism, ovulatory dysfunction observed as the length of the menstrual cycle and duration of bleeding (Rashidi et al. 2017) and altered ovarian morphology.

\section{Conclusion}

Since the studies on gene expression in BPA-induced PCOS models are relatively limited, this review encapsulates the effect of BPA on the expression of 28 genes that take part in various metabolic and endocrinal pathways, whose disruption may play a major role in the pathogenesis of PCOS.

Acknowledgements This study was supported by the Indian Council of Medical Research (ICMR) (Grant No. 2020-6122/CMB-BMS) and Manipal School of Life Sciences, Manipal Academy of Higher Education, Manipal, India.

Author contribution The concept was initiated by PSR and NBP; literature search and data interpretation were performed by RM and NBP. The manuscript was written by RM. PSR and SPK critically reviewed the manuscript.

Funding Open access funding provided by Manipal Academy of Higher Education, Manipal. 
Data availability Not applicable.

\section{Declarations}

Ethics approval and consent to participate Not applicable.

Consent for publication Not applicable.

Competing interests The authors declare no competing interests.

Open Access This article is licensed under a Creative Commons Attribution 4.0 International License, which permits use, sharing, adaptation, distribution and reproduction in any medium or format, as long as you give appropriate credit to the original author(s) and the source, provide a link to the Creative Commons licence, and indicate if changes were made. The images or other third party material in this article are included in the article's Creative Commons licence, unless indicated otherwise in a credit line to the material. If material is not included in the article's Creative Commons licence and your intended use is not permitted by statutory regulation or exceeds the permitted use, you will need to obtain permission directly from the copyright holder. To view a copy of this licence, visit http://creativecommons.org/licenses/by/4.0/.

\section{References}

Adachi S, Yamada S, Takatsu Y, Matsui H, Kinoshita M, Takase K, Sugiura H, Ohtaki T, Matsumoto H, Uenoyama Y, Tsukamura H, Inoue K, Maeda K (2007) Involvement of anteroventral periventricular metastin/kisspeptin neurons in estrogen positive feedback action on luteinizing hormone release in female rats. J Reprod Dev 53:367-378. https://doi.org/10.1262/jrd.18146

Adewale HB, Jefferson WN, Newbold RR, Patisaul HB (2009) Neonatal bisphenol-a exposure alters rat reproductive development and ovarian morphology without impairing activation of gonadotropin-releasing hormone neurons. Biol Reprod 81:690-699. https:// doi.org/10.1095/biolreprod.109.078261

Ahmed F, Sarsenbayeva A, Katsogiannos P, Aguer C, Pereira MJ (2020) The effects of bisphenol A and bisphenol S on adipokine expression and glucose metabolism in human adipose tissue. Toxicology 445:152600. https://doi.org/10.1016/j.tox.2020.152600

Aluru N, Leatherland JF, Vijayan MM (2010) Bisphenol A in oocytes leads to growth suppression and altered stress performance in juvenile rainbow trout. PLoS ONE 5:e10741. https://doi.org/10. 1371/journal.pone.0010741

Arase S, Ishii K, Igarashi K, Aisaki K, Yoshio Y, Matsushima A, Shimohigashi Y, Arima K, Kanno J, Sugimura Y (2011) Endocrine disrupter bisphenol A increases in situ estrogen production in the mouse urogenital sinus. Biol Reprod 84:734-742. https://doi.org/ 10.1095/biolreprod.110.087502

Ariemma F, D'Esposito V, Liguoro D, Oriente F, Cabaro S, Liotti A, Cimmino I, Longo M, Beguinot F, Formisano P, Valentino R (2016) Low-dose Bisphenol-A impairs adipogenesis and generates dysfunctional 3T3-L1 adipocytes. PLoS One 11(3):e0150762. https://doi.org/10.1371/journal.pone.0150762

Azziz R, Carmina E, Chen Z, Dunaif A, Laven JS, Legro RS, Lizneva D, Natterson-Horowtiz B, Teede HJ, Yildiz BO (2016) Polycystic ovary syndrome. Nat Rev Dis Primers 2:16057. https://doi.org/10. 1038/nrdp. 2016.57

Belenkaia LV, Lazareva LM, Walker W, Lizneva DV, Suturina LV (2019) Criteria, phenotypes and prevalence of polycystic ovary syndrome. Minerva Ginecol 71:211-223. https://doi.org/10. 23736/s0026-4784.19.04404-6
Cao Y, Qu X, Ming Z, Yao Y, Zhang Y (2018) The correlation between exposure to BPA and the decrease of the ovarian reserve. Int J Clin Exp Pathol 11:3375-3382

Chu PW, Yang ZJ, Huang HH, Chang AA, Cheng YC, Wu GJ, Lan HC (2018) Low-dose bisphenol A activates the ERK signaling pathway and attenuates steroidogenic gene expression in human placental cells. Biol Reprod 98:250-258. https://doi.org/10.1093/ biolre/iox 162

Cimmino I, Fiory F, Perruolo G, Miele C, Beguinot F, Formisano P, Oriente F (2019) Potential mechanisms of bisphenol A (BPA) contributing to human disease. Int J Mol Sci 21:5761. https://doi. org/10.3390/ijms21165761

Déchaud H, Ravard C, Claustrat F, de la Perrière AB, Pugeat M (1999) Xenoestrogen interaction with human sex hormone-binding globulin (hSHBG). Steroids 64:328-334. https://doi.org/10.1016/ s0039-128x(98)00114-7

Dungan HM, Clifton DK, Steiner RA (2006) Minireview: kisspeptin neurons as central processors in the regulation of gonadotropinreleasing hormone secretion. Endocrinology 147:1154-1158. https://doi.org/10.1210/en.2005-1282

Encarnação T, Pais AA, Campos MG, Burrows HD (2019) Endocrine disrupting chemicals: Impact on human health, wildlife and the environment. Sci Prog 102:3-42. https://doi.org/10.1177/00368 50419826802

Escobar-Morreale HF (2018) Polycystic ovary syndrome: definition, aetiology, diagnosis and treatment. Nat Rev Endocrinol 14:270 284. https://doi.org/10.1038/nrendo.2018.24

Faheem M, Khaliq S, Lone KP (2017) Disruption of the reproductive axis in freshwater fish, Catla catla, After Bisphenol-A Exposure. Zoolog Sci 34:438-444. https://doi.org/10.2108/zs170009

Fan AM, Chow WC, Lin P (2017) Toxicity and risk assessment of bisphenol A. Reproductive and Developmental Toxicology 765-795. https://doi.org/10.1016/B978-0-12-804239-7.00041-X

Fang H, Tong W, Perkins R, Soto AM, Prechtl NV, Sheehan DM (2000) Quantitative comparisons of in vitro assays for estrogenic activities. Environ Health Perspect 108:723-729. https://doi.org/10. 1289/ehp.00108723

Fernández M, Bianchi M, Lux-Lantos V, Libertun C (2009) Neonatal exposure to bisphenol a alters reproductive parameters and gonadotropin releasing hormone signaling in female rats. Environ Health Perspect 117:757-762. https://doi.org/10.1289/ehp.08002 67

Fernández M, Bourguignon N, Lux-Lantos V, Libertun C (2010) Neonatal exposure to bisphenol a and reproductive and endocrine alterations resembling the polycystic ovarian syndrome in adult rats. Environ Health Perspect 118:1217-1222. https://doi.org/10. 1289/ehp.0901257

Gámez JM, Penalba R, Cardoso N, Bernasconi PS, Carbone S, Ponzo O, Pandolfi M, Scacchi P, Reynoso R (2015) Exposure to a low dose of bisphenol A impairs pituitary-ovarian axis in prepubertal rats: effects on early folliculogenesis. Environ Toxicol Pharmacol 39:9-15. https://doi.org/10.1016/j.etap.2014.10.015

Gruijters MJ, Visser JA, Durlinger AL, Themmen AP (2003) AntiMüllerian hormone and its role in ovarian function. Mol Cell Endocrinol 211:85-90. https://doi.org/10.1016/j.mce.2003.09.024

Hanioka N, Naito T, Narimatsu S (2008) Human UDP-glucuronosyltransferase isoforms involved in bisphenol A glucuronidation. Chemosphere 74:33-36. https://doi.org/10.1016/j.chemosphere. 2008.09.053

Hannon PR, Flaws JA (2015) The effects of phthalates on the ovary. Front Endocrinol (Lausanne) 6:8. https://doi.org/10.3389/fendo. 2015.00008

Haq MEU, Akash MSH, Rehman K, Mahmood MH (2020) Chronic exposure of bisphenol A impairs carbohydrate and lipid metabolism by altering corresponding enzymatic and metabolic 
pathways. Environ Toxicol Pharmacol 78:103387. https://doi. org/10.1016/j.etap.2020.103387

Hong YP and Yang YJ (2017) Low-Dose Exposure to Bisphenol A in Early Life, Bisphenol A exposure and health risks. IntechOpen. https://www.intechopen.com/chapters/54936

Ijaz S, Ullah A, Shaheen G, Jahan S (2020) Exposure of BPA and its alternatives like BPB, BPF, and BPS impair subsequent reproductive potentials in adult female Sprague Dawley rats. Toxicol Mech Methods 30:60-72. https://doi.org/10.1080/15376516.2019. 1652873

Iso T, Watanabe T, Iwamoto T, Shimamoto A, Furuichi Y (2006) DNA damage caused by bisphenol A and estradiol through estrogenic activity. Biol Pharm Bull 29:206-210. https://doi.org/10.1248/ bpb.29.206

Jurewicz J, Majewska J, Berg A, Owczarek K, Zajdel R, Kaleta D, Wasik A, Rachoń D (2021) Serum bisphenol A analogues in women diagnosed with the polycystic ovary syndrome - is there an association? Environ Pollut 272:115962. https://doi.org/10. 1016/j.envpol.2020.115962

Kandaraki E, Chatzigeorgiou A, Livadas S, Palioura E, Economou F, Koutsilieris M, Palimeri S, Panidis D, Diamanti-Kandarakis E (2011) Endocrine disruptors and polycystic ovary syndrome (PCOS): elevated serum levels of bisphenol A in women with PCOS. J Clin Endocrinol Metab 96:480-484. https://doi.org/10. 1210/jc.2010-1658

Kang JH, Kondo F, Katayama Y (2006) Human exposure to bisphenol A. Toxicology 226(2-3):79-89. https://doi.org/10.1016/j.tox. 2006.06.009

Kang NH, Hwang KA, Lee HR, Choi DW, Choi KC (2013) Resveratrol regulates the cell viability promoted by $17 \beta$-estradiol or bisphenol A via down-regulation of the cross-talk between estrogen receptor $\alpha$ and insulin growth factor-1 receptor in BG-1 ovarian cancer cells. Food Chem Toxicol 59:373-379. https://doi.org/10.1016/j. fct.2013.06.029

Khan NG, Correia J, Adiga D, Rai PS, Dsouza HS, Chakrabarty S, Kabekkodu SP (2021) A comprehensive review on the carcinogenic potential of bisphenol A: clues and evidence. Environ Sci Pollut Res Int 28:19643-19663. https://doi.org/10.1007/ s11356-021-13071-w

Kinoshita M, Tsukamura H, Adachi S, Matsui H, Uenoyama Y, Iwata K, Yamada S, Inoue K, Ohtaki T, Matsumoto H, Maeda K (2005) Involvement of central metastin in the regulation of preovulatory luteinizing hormone surge and estrous cyclicity in female rats. Endocrinology 146:4431-4436. https://doi.org/10.1210/en. 2005-0195

Li Y, Zhang W, Liu J, Wang W, Li H, Zhu J, Weng S, Xiao S, Wu T (2014) Prepubertal bisphenol A exposure interferes with ovarian follicle development and its relevant gene expression. Reprod Toxicol 44:33-40. https://doi.org/10.1016/j.reprotox.2013.09.002

Liu KC, Wu RS, Ge W (2013) Luteinizing hormone receptor (lhcgr) as a marker gene for characterizing estrogenic endocrine-disrupting chemicals in zebrafish ovarian follicle cells. Gen Comp Endocrinol 192:89-94. https://doi.org/10.1016/j.ygcen.2013.06.023

Meier RK (2018) Polycystic Ovary Syndrome. Nurs Clin North Am 53:407-420. https://doi.org/10.1016/j.cnur.2018.04.008

Melzer D, Harries L, Cipelli R, Henley W, Money C, McCormack P, Young A, Guralnik J, Ferrucci L, Bandinelli S, Corsi AM, Galloway T (2011) Bisphenol A exposure is associated with in vivo estrogenic gene expression in adults. Environ Health Perspect 119:1788-1793. https://doi.org/10.1289/ehp.1103809

Menale C, Grandone A, Nicolucci C, Cirillo G, Crispi S, Di Sessa A, Marzuillo P, Rossi S, Mita DG, Perrone L, Diano N, Miraglia Del Giudice E (2017) Bisphenol A is associated with insulin resistance and modulates adiponectin and resistin gene expression in obese children. Pediatr Obes 12:380-387. https://doi.org/10.1111/ ijpo. 12154
Miao S, Gao Z, Kou Z, Xu G, Su C, Liu N (2008) Influence of bisphenol a on developing rat estrogen receptors and some cytokines in rats: a two-generational study. J Toxicol Environ Health A 71:1000-1008. https://doi.org/10.1080/15287390801907467

Michałowicz J (2014) Bisphenol A-sources, toxicity and biotransformation. Environ Toxicol Pharmacol 37:738-758. https://doi.org/ 10.1016/j.etap.2014.02.003

Monje L, Varayoud J, Muñoz-de-Toro M, Luque EH, Ramos JG (2010) Exposure of neonatal female rats to bisphenol A disrupts hypothalamic LHRH pre-mRNA processing and estrogen receptor alpha expression in nuclei controlling estrous cyclicity. Reprod Toxicol 30:625-634. https://doi.org/10.1016/j.reprotox.2010.08.004

Peretz J, Flaws JA (2013) Bisphenol A down-regulates rate-limiting Cyp11a1 to acutely inhibit steroidogenesis in cultured mouse antral follicles. Toxicol Appl Pharmacol 271:249-256. https:// doi.org/10.1016/j.taap.2013.04.028

Prabhu BN, Kanchamreddy SH, Sharma AR, Bhat SK, Bhat PV, Kabekkodu SP, Satyamoorthy K, Rai PS (2021) Conceptualization of functional single nucleotide polymorphisms of polycystic ovarian syndrome genes: an in silico approach. J Endocrinol Invest 44:1783-1793. https://doi.org/10.1007/s40618-021-01498-4

Provencher G, Bérubé R, Dumas P, Bienvenu JF, Gaudreau E, Bélanger P, Ayotte P (2014) Determination of bisphenol A, triclosan and their metabolites in human urine using isotope-dilution liquid chromatography-tandem mass spectrometry. J Chromatogr A 1348:97-104. https://doi.org/10.1016/j.chroma.2014.04.072

Qiu J, Sun Y, Sun W, Wang Y, Fan T, Yu J (2020) Neonatal exposure to bisphenol A advances pubertal development in female rats. Mol Reprod Dev 87:503-511. https://doi.org/10.1002/mrd.23329

Qin F, Wang L, Wang X, Liu S, Xu P, Wang H, Wu T, Zhang Y, Zheng Y, Li M, Zhang X, Yuan C, Hu G, Wang Z (2012) Bisphenol A affects gene expression of gonadotropin-releasing hormones and type I GnRH receptors in brains of adult rare minnow Gobiocypris rarus. Comp Biochem Physiol C Toxicol Pharmacol 157:192-202. https://doi.org/10.1016/j.cbpc.2012.11.002

Rashidi BH, Amanlou M, Behrouzi Lak T, Ghazizadeh M, Haghollahi F, Bagheri M, Eslami B (2017) The association between bisphenol A and polycystic ovarian syndrome: a case-control study. Acta Med Iran 55:759-764

Renaud L, Huff M, da Silveira WA, Angert M, Haas M, Hardiman G (2019) Genome-Wide Analysis of Low Dose Bisphenol-A (BPA) Exposure in Human Prostate Cells. Curr Genomics 20:260-274. https://doi.org/10.2174/1389202920666190603123040

Richter CA, Birnbaum LS, Farabollini F, Newbold RR, Rubin BS, Talsness CE, Vandenbergh JG, Walser-Kuntz DR, vom Saal FS (2007) In vivo effects of bisphenol A in laboratory rodent studies. Reprod Toxicol 24:199-224. https://doi.org/10.1016/j.repro tox.2007.06.004

Rodríguez HA, Santambrosio N, Santamaría CG, Muñoz-de-Toro M, Luque EH (2010) Neonatal exposure to bisphenol A reduces the pool of primordial follicles in the rat ovary. Reprod Toxicol 30:550-557. https://doi.org/10.1016/j.reprotox.2010.07.008

Rutkowska A, Rachoń D (2014) Bisphenol A (BPA) and its potential role in the pathogenesis of the polycystic ovary syndrome (PCOS). Gynecol Endocrinol 30:260-265. https://doi.org/10.3109/09513 590.2013.871517

Samardzija D, Pogrmic-Majkic K, Fa S, Stanic B, Jasnic J, Andric $\mathrm{N}$ (2018) Bisphenol A decreases progesterone synthesis by disrupting cholesterol homeostasis in rat granulosa cells. Mol Cell Endocrinol 461:55-63. https://doi.org/10.1016/j.mce.2017.08.013

Shi J, Liu C, Chen M, Yan J, Wang C, Zuo Z, He C (2021) The interference effects of bisphenol A on the synthesis of steroid hormones in human ovarian granulosa cells. Environ Toxicol 36:665-674. https://doi.org/10.1002/tox.23070

Takeuchi T, Tsutsumi O, Ikezuki Y, Takai Y, Taketani Y (2004) Positive relationship between androgen and the endocrine disruptor, 
bisphenol A, in normal women and women with ovarian dysfunction. Endocr J 51:165-169. https://doi.org/10.1507/endocrj.51.165

Takeuchi T, Tsutsumi O, Ikezuki Y, Kamei Y, Osuga Y, Fujiwara T, Takai Y, Momoeda M, Yano T, Taketani Y (2006) Elevated serum bisphenol A levels under hyperandrogenic conditions may be caused by decreased UDP-glucuronosyltransferase activity. Endocr J 53:485-491. https://doi.org/10.1507/endocrj.k06-032

Tarantino G, Valentino R, Di Somma C, D'Esposito V, Passaretti F, Pizza G, Brancato V, Orio F, Formisano P, Colao A, Savastano S (2013) Bisphenol A in polycystic ovary syndrome and its association with liver-spleen axis. Clin Endocrinol (oxf) 78:447-453. https://doi.org/10.1111/j.1365-2265.2012.04500.x

Vahedi M, Saeedi A, Poorbaghi SL, Sepehrimanesh M, Fattahi M (2016) Metabolic and endocrine effects of bisphenol A exposure in market seller women with polycystic ovary syndrome. Environ Sci Pollut Res Int 23:23546-23550. https://doi.org/10.1007/ s11356-016-7573-5

Vermeulen A (1993) Environment, human reproduction, menopause, and andropause. Environ Health Perspect 101(Suppl 2):91-100. https://doi.org/10.1289/ehp.93101s291

Wang X, Chang F, Bai Y, Chen F, Zhang J, Chen L (2014) Bisphenol A enhances kisspeptin neurons in anteroventral periventricular nucleus of female mice. J Endocrinol 221:201-213. https://doi. org/10.1530/joe-13-0475

Wang Y, Zhu Q, Dang X, He Y, Li X, Sun Y (2017) Local effect of bisphenol A on the estradiol synthesis of ovarian granulosa cells from PCOS. Gynecol Endocrinol 33:21-25. https://doi.org/10. 1080/09513590.2016.1184641

Warita K, Mitsuhashi T, Ohta K, Suzuki S, Hoshi N, Miki T, Takeuchi Y (2013) In vitro evaluation of gene expression changes for gonadotropin-releasing hormone 1, brain-derived neurotrophic factor and neurotrophic tyrosine kinase, receptor, type 2, in response to bisphenol A treatment. Congenit Anom (kyoto) 53:42-45. https:// doi.org/10.1111/j.1741-4520.2012.00381.x

Watanabe M, Ohno S, Nakajin S (2012) Effects of bisphenol A on the expression of cytochrome P450 aromatase (CYP19) in human fetal osteoblastic and granulosa cell-like cell lines. Toxicol Lett 210:95-99. https://doi.org/10.1016/j.toxlet.2012.01.020

Wetherill YB, Akingbemi BT, Kanno J, McLachlan JA, Nadal A, Sonnenschein C, Watson CS, Zoeller RT, Belcher SM (2007) In vitro molecular mechanisms of bisphenol A action. Reprod Toxicol 24:178-198. https://doi.org/10.1016/j.reprotox.2007.05.010

Xi W, Lee CK, Yeung WS, Giesy JP, Wong MH, Zhang X, Hecker M, Wong CK (2011) Effect of perinatal and postnatal bisphenol A exposure to the regulatory circuits at the hypothalamus-pituitarygonadal axis of CD-1 mice. Reprod Toxicol 31:409-417. https:// doi.org/10.1016/j.reprotox.2010.12.002

Yilmaz B, Terekeci H, Sandal S, Kelestimur F (2020) Endocrine disrupting chemicals: exposure, effects on human health, mechanism of action, models for testing and strategies for prevention. Rev Endocr Metab Disord 21:127-147. https://doi.org/10.1007/ s11154-019-09521-z

Zhang T, Guan Y, Wang S, Wang L, Cheng M, Yuan C, Liu Y, Wang Z (2018) Bisphenol A induced abnormal DNA methylation of ovarian steroidogenic genes in rare minnow Gobiocypris rarus. Gen Comp Endocrinol 269:156-165. https://doi.org/10.1016/j. ygcen.2018.09.009

Zhang T, Liu Y, Chen H, Gao J, Zhang Y, Yuan C, Wang Z (2017) The DNA methylation status alteration of two steroidogenic genes in gonads of rare minnow after bisphenol A exposure. Comp Biochem Physiol C Toxicol Pharmacol 198:9-18. https://doi.org/10. 1016/j.cbpc.2017.05.001

Zhou W, Fang F, Zhu W, Chen ZJ, Du Y, Zhang J (2017) Bisphenol A and Ovarian Reserve among Infertile Women with Polycystic Ovarian Syndrome. Int J Environ Res Public Health 14:18. https:// doi.org/10.3390/ijerph14010018

Zhou W, Liu J, Liao L, Han S, Liu J (2008) Effect of bisphenol A on steroid hormone production in rat ovarian theca-interstitial and granulosa cells. Mol Cell Endocrinol 283:12-18. https://doi.org/ 10.1016/j.mce.2007.10.010

Zhu X, Tian GG, Yu B, Yang Y, Wu J (2018) Effects of bisphenol A on ovarian follicular development and female germline stem cells. Arch Toxicol 92:1581-1591. https://doi.org/10.1007/ s00204-018-2167-2

Publisher's Note Springer Nature remains neutral with regard to jurisdictional claims in published maps and institutional affiliations. 